\title{
Slepian-Wolf の定理
}

一相関のある情報源の分散符号化

\section{The Slepian-Wolf Theorem}

-Distributed Coding of Correlated Sources

村松 純 Jun MURAMATSU

アブストラクト D. Slepian と J. K. Wolf が 1973 年に発表した相関のある情報源の分散符号化問題に関する定理とその後の 発展について，順定理の証明手法（符号の構成）という視点から解説する.

キーワード 情報理論, 情報圧縮, 多端子情報源符号化, 分散符号化, Slepian-Wolf の定理

Abstract In 1973, D. Slepian and J. K. Wolf proved a theorem on the coding problem of correlated sources. The history of this theorem is reviewed from the viewpoint of achievability proofs (code constructions).

Key words Information Theory, Data Compression, Multiterminal Source Coding, Distributed Source Coding, SlepianWolf Theorem

\section{1. はじめに}

1973 年に D. Slepian と J. K. Wolf は多端子情報理論(注1) に関する二つの論文を発表した .一つは , 相関(注2) を有する二つ の情報源の分散符号化に関する論文 ${ }^{(5)}$ である .もう一つは , 二 つの符号器が私的なメッセージに加えて共通のメッセージを有 しているときのマルチプルアクセス通信路の符号化に関する論

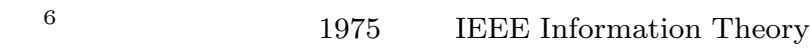
Society Paper Award を受賞した前者の論文と光の後の発展に ついて, 順定理の証明手法 (符号の構成) という視点から解説 を試みたいと思う(注3)。

情報理論研究者でなければ, 「Slepian-Wolf の定理」と聞いて もピンと来ない方がほとんどのような気がする．実際，この定 理の完全な証明が書かれている日本語で書かれた情報理論の教 科書は少ない(注4) . 本稿では, この定理を初めて知る読者にも分 かるように, 数列の極限, 確率, 有限体上の線形代数とこれか ら紹介する幾つかの補題を認めて頂いた上で, 順定理の証明を 直観的に説明したい(注5).

ここで，あらかじめ約束しておきたいことをまとめておく. 特 に断らない限り，ここで扱う情報源や通信路は全て有限集合上 で定義されたもので，定常無記憶性を持っているとする．確率

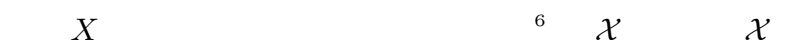
要素 $\left(X\right.$ の実現值の一つ) を $x$ と記し, $\mathcal{X}^{n}$ の要素 $\left(X^{n}\right.$ の実 現値の一つ) を $x^{n}$ と記す .ここで,$X^{n} や x^{n}$ がベクトルであ

村松 純 正員 日本電信電話株式会社 NTT コミュニケーション科学基礎研究所 E-mail muramatsu.jun@lab.ntt.co.jp

Jun MURAMATSU, Member (NTT Communication Science Laboratories, Nippon Telegraph and Telephone Corporation, Kyoto-fu 6190237 Japan).

電子情報通信学会 基礎・境界ソサイエティ

Fundamentals Review Vol.7 No.3 pp.227-241 2014 年 1 月 (C)電子情報通信学会 2014
るときは全て列ベクトルであるとし，転置記号を省略する，確 率変数 $X$ と対応する確率分布を $p_{X}$ と記す.また,$X^{n}$ と対応 する確率分布も $p_{X}$ と記す ${ }^{(\text {注 } 7)} . Y$ などのほかの確率变数につ いても同樣の記法を用いるが, 関数や行列, 弚してこれらと対 応する確率変数をどちらも $A$ などと表記する場合がある. $n$ 次 元の零ベクトル $(n$ 個の 0 を並べた系列 $) を 0^{n}$ と記す. 有限 体及び有限体上のベクトル空間の加法, 減法を关れ光れ,+と表記する.最後に, 演算の優先順位を [.] で示し , (·) は関数 の引数を表現するために用いていることを注意しておく.ただ し，[0,1] は閉区間を表しており，自然言語で定義を与えるとき も [·] を用いている.(·) は行列, ベクトルを表現するときにも 用いる $\cdot|\cdot|$ は絶対値あるいは集合の要素数を表す .

\section{Slepian-Wolf の定理}

本稿で解説する Slepian-Wolf の定理は，相関のある二つの 情報源の出力 $X^{n}, Y^{n}$ を他方の出力を観測せずに個別に符号 化 (圧縮) し, 二つの符号語 $U^{n R_{X}}, V^{n R_{Y}} \quad\left(R_{X}, R_{Y}\right.$ は正

(注1) : 複数の入力端子と出力端子 (入力端子と出力端子の少なくともどちらかは二 つ以上) を持つ通信路に関する符号化の理論 . 情報源符号化問題は無雑音の通信路を 仮定して 2 個以上の情報源の圧縮レートを議論し, 通信路符号化問題は染倠音のある 通信路を仮 定して 2 個以上のメッセージの伝送レートを議論する.

(注2) : 数学的には, $X$ と $Y$ に相関があるとは, $X$ と $Y$ が独立ではない場合を 指す.

(注3) : 本稿では，歴史的経緯の把握を容易にするために論文の参照番号を時系列順 とした ・ただし, 本論文以前に発表された会議論文が存在する場合もあるので, 時系 列は必ずしも厳密ではない

(注4)：筆者か調べた範囲では, 文献(12)，(18),(19)，(51)ぐらいしか見当たら なかった。

(注5) : 要点だけを簡潔に知りたい場合は本稿の基になった予稿 ${ }^{(57)}$ を御覽頂きたい (注6) : アルファベットと呼ばれる.

(注7) : 実際, $X^{n}$ が定常無記憶のときには $X^{n}$ の分布は $X$ の分布 $p_{X}$ により定 まる。 


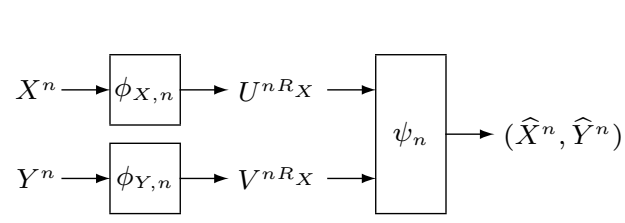

図 1 Slepian-Wolf 情報源符号化

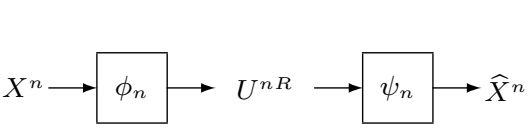

図 2 情報源符号化

の実数) を受信した復号器が $X^{n}, Y^{n}$ の両方を 0 に限りなく 近い誤り確率で復号する場合（図 1) を論じたものである . 以 後，このような符号を Slepian-Wolf 符号と呼ぶことにする． 相関のある情報源の例として，

- 離れている複数のセンサが持つ情報(注8)

・ ステレオ音声の右音声と左音声

・ 静止画像の隣接するピクセル情報

- 動画像の連続するフレーム情報

などを挙げることができる .これらはいずれも，一方の情報か ら他方の情報が推測しやすい．このような複数の情報源の持つ 相関を利用するように設計された符号が Slepian-Wolf 符号であ る. 複数の情報源の出力を個別に符号化できるために符号器の 実装が簡単になるという特徵から，最近は上記のような実デー タに対する Slepian-Wolf 符号を実装するという研究も行われ ている(55). また Slepian-Wolf 符号は「相関乱数からの秘密鍵 共有」と呼ばれるセキュリティ技術にも応用できることが知ら れている(30),(37),(56)

本章では，最初に Shannon の情報源符号化定理を復習し，続 いて相関のある情報源の簡単な例を用いて Slepian-Wolf 符号 を説明し，最後に Slepian-Wolf の定理を形式的に述べる。

\section{1 情報源符号化定理}

Slepian-Wolf の定理を説明する前に，Shannon が証明した 情報源符号化定理 ${ }^{(1)}$ を簡単に復習させて頂きたい .ここでは， 一つの情報源の出力を符号 (圧縮) して符号語 $U^{n R}$ を出力し 復号器が受信した $U^{n R}$ を復号化して $X^{n}$ を 0 に限りなく近い 復号誤り確率で再生する場合（図 2) を考える。

符号器は関数 $\phi_{n}: \mathcal{X}^{n} \rightarrow\{0,1\}^{n R}$ と表現することができ る (注9).ここで， $R \geqq 0$ は符号化レートと呼ばれる. 復号器を 関数 $\psi_{n}:\{0,1\}^{n R} \rightarrow \mathcal{X}^{n}$ と表現したとき，復号誤り確率は

$$
\operatorname{Prob}\left(\psi_{n}\left(\phi_{n}\left(X^{n}\right)\right) \neq X^{n}\right)
$$

となる .

Shannon は情報理論に関する最初の論文 ${ }^{(1)}$ で次の定理を証 明した . 情報源 $X$ のエントロピー $H(X)$ を以下のように定義

(注 8) : 複数のセンサが適切な距離を保たないとほとんど独立になってしまうだろう (注9) $: n R$ か整数でない場合は切り上げる必要があるが, $n \rightarrow \infty$ とともに符号化 レートへの影響を無視することができるので, $n R$ が整数であるかのような表記をす る. 以後同樣の表記をする .
する .

$$
H(X) \equiv \sum_{x \in \mathcal{X}} p_{X}(x) \log _{2} \frac{1}{p_{X}(x)}
$$

定理 1 (順定理). 符号化レート $R$ が $R>H(X)$ を満たすと き，復号誤り確率が $n \rightarrow \infty$ とともに 0 に収束するような符 号(注10) $\left\{\left(\phi_{n}, \psi_{n}\right)\right\}_{n=1}^{\infty}$ が存在する .

定理 2 (逆定理). 復号誤り確率が $n \rightarrow \infty$ とともに 0 に収束 するような全ての符号 $\left\{\left(\phi_{n}, \psi_{n}\right)\right\}_{n=1}^{\infty}$ は $R \geqq H(X)$ を満たし ている .

ここで，順定理では， $n \rightarrow \infty, R \rightarrow H(X)$ とすることによ り $H(X)$ に限りなく近い符号化レートを持つ符号が存在すると みなしてもよい. 以上の二つの定理から, 情報源 $X$ のエントロ ピー $H(X)$ が $X$ を符号化 (圧縮) するときのレートの限界で あると結論付けることができる(注11)

ここで，順定理の証明を簡単に説明したい .これは SlepianWolf の証明を理解する上で重要になる . 今から紹介する証明は Shannon の最初の論文の証明に沿ったものである .

まず，典型集合と呼ばれる以下で定義された $\mathcal{X}^{n}$ の部分集合 $\mathcal{T}_{X, \varepsilon}^{n}$ を導入する .

$$
\mathcal{T}_{X, \varepsilon}^{n} \equiv\left\{x^{n}:\left|\frac{1}{n} \log _{2} \frac{1}{p_{X}\left(x^{n}\right)}-H(X)\right| \leqq \varepsilon\right\}
$$

Shannon は定常無記憶情報源 $X$ に対して次の補題を証明し た ${ }^{(1)}$.

補題 1. 任意の $\varepsilon>0$ に対して $n \rightarrow \infty$ とともに

$$
\operatorname{Prob}\left(X^{n} \in \mathcal{T}_{X, \varepsilon}^{n}\right) \rightarrow 1
$$

となる

この補題を認めて頂ければ，順定理の証明は簡単である．ま ず, 集合 $\mathcal{T}_{X, \varepsilon}^{n}$ の要素数 $\left|\mathcal{T}_{X, \varepsilon}^{n}\right|$ を評価する.

$$
\begin{aligned}
\left|\mathcal{T}_{X, \varepsilon}^{n}\right| & =\sum_{x^{n} \in \mathcal{T}_{X, \varepsilon}^{n}} 1 \\
& \leqq \sum_{x^{n} \in \mathcal{T}_{X, \varepsilon}^{n}} p_{X}\left(x^{n}\right) 2^{n[H(X)+\varepsilon]} \\
& \leqq 2^{n[H(X)+\varepsilon]}
\end{aligned}
$$

ここで, 最初の不等式では任意の $x^{n} \in \mathcal{T}_{X, \varepsilon}^{n}$ で

$$
\frac{1}{n} \log _{2} \frac{1}{p_{X}\left(x^{n}\right)} \leqq H(X)+\varepsilon
$$

が成り立つことを，光の次の不等式では $2^{n[H(X)+\varepsilon]}$ を $\sum$ 外 に出した上で確率の総和が 1 以下であることを用いた . 式 (3) は, $\mathcal{T}_{X, \varepsilon}^{n}$ の要素を $n[H(X)+\varepsilon]$ ビットで表されるインデック スにより一意に特定できることを意味する．符号を次のように

(注10) : 本稿では符号器と復号器の組の列のことを符号と呼ぶ

(注11) : 情報理論になじみのない読者のために補足させて頂くと， $H(X)$ の定義に は符号 $\left\{\left(\phi_{n}, \psi_{n}\right)\right\}_{n=1}^{\infty}$ は現れず, $X$ の確率分布だけで求められる量であることが 重要である.一般に Shannon 理論では, 通信をはじめとする情報処理のある種の 限界を, あらかじめ仮定した情報源や通信路の性質 (確率分布) だけを用いて記述す ることを目標とする 
表 1 相関のある情報源の同時分布の例

\begin{tabular}{|c|c|c|c|c|c|c|}
\hline & $X=0$ & $X=1$ & $X=2$ & $X=3$ & $X=4$ & $X=5$ \\
\hline$Y=1$ & $1 / 12$ & $1 / 12$ & $1 / 12$ & 0 & 0 & 0 \\
\hline$Y=2$ & 0 & $1 / 12$ & $1 / 12$ & $1 / 12$ & 0 & 0 \\
\hline$Y=3$ & 0 & 0 & $1 / 12$ & $1 / 12$ & $1 / 12$ & 0 \\
\hline$Y=4$ & 0 & 0 & 0 & $1 / 12$ & $1 / 12$ & $1 / 12$ \\
\hline
\end{tabular}

構成する．

- 符号器は, もしも情報源の出力 $x^{n}$ が $\mathcal{T}_{X, \varepsilon}^{n}$ の要素であ れば，これを $n[H(X)+\varepsilon]$ ビットで符号化する .もしも $x^{n}$ が $\mathcal{T}_{X, \varepsilon}^{n}$ の要素でなければ $n[H(X)+\varepsilon]$ 個の 0 を符号語とする すなわち, 符号器 $\phi_{n}$ は以下のようになる.

$\phi_{n}\left(x^{n}\right) \equiv \begin{cases}{[n[H(X)+\varepsilon] \text { ビットの符号語 }],} & x^{n} \in \mathcal{T}_{X, \varepsilon}^{n} \text { のとき } \\ 0^{n[H(X)+\varepsilon],} & x^{n} \notin \mathcal{T}_{X, \varepsilon}^{n} \text { のとき }\end{cases}$

符号化レートは $R=H(X)+\varepsilon$ となる.

- 復号器は, 受信した符号語 $u^{n R}$ から唯一定まる $\mathcal{T}_{X, \varepsilon}^{n}$ の 要素を再生する . 復号器 $\psi_{n}$ は以下のようになる.

$$
\psi_{n}\left(u^{n R}\right) \equiv\left[\text { 符号語 } u^{n R} \text { と対応する } x^{n} \in \mathcal{T}_{X, \varepsilon}^{n}\right]
$$

ここで, 復号誤りが生じるのは $x^{n} \notin \mathcal{T}_{X, \varepsilon}^{n}$ であったときのみで あることに注目すると，復号誤り確率は $\left[1-\operatorname{Prob}\left(X^{n} \in \mathcal{T}_{X, \varepsilon}^{n}\right)\right]$ となる . したがって, 補題 2 より復号誤り確率は $n \rightarrow \infty$ とと もに 0 に収束する $. \varepsilon>0$ は任意であったので， $R>H(X)$ を 満たせば復号誤り確率が $n \rightarrow \infty$ とともに 0 に収束するような 符号が存在することが分かった .

後の理解のために覚えておいて頂きたいのは, 要素数が高々 $2^{n[H(X)+\varepsilon]}$ であり，かつ確率が 1 に近い集合 $\mathcal{T}_{X, \varepsilon}^{n}$ が存在する ことである . この集合にある要素を特定できれば , 情報源出力 $X^{n}$ を 0 に近い復号誤り確率で符号化できることになる。

\section{2 相関のある情報源の符号化}

ここでは, 表 1 のような同時分布を持つ二つの情報源 $X$ と $Y$ を考えてみよう .この例(注12)では， $Y$ の值を観測すれば， $X$ は $|X-Y| \leqq 1$ を満たす範囲の整数值しかとらないことが推測 できるので，相関を有していることが分かる．

まず最初に，相関を利用せずに情報源 $X$ と $Y$ を 個別に符号化 (圧縮) してみよう. $X$ の周辺分布 ${ }^{\left(\text {II }^{13)}\right.}{ }^{13}$ $(1 / 12,1 / 6,1 / 4,1 / 4,1 / 6,1 / 12)$ となる .これは，表 1 で各 列の確率の総和を求めることにより計算できる . 同樣に , 表 1 の各行の確率の総和によって $Y$ の周辺分布を求める と, 乥れ艺れの確率が $1 / 4$ の一樣分布であることが分か る.したがって, 前節の情報源符号化定理から， $X$ をレート $H(X)=\frac{1}{6} \log _{2} 12+\frac{1}{3} \log _{2} 6+\frac{1}{2} \log _{2} 4$ で符号化(注14) して , $Y$

(注12) : この例は 2013 年 3 月の情報理論研究会での NTT の仲地主任研究員に よる招待講演 ${ }^{55)}$ で紹介された例を参考にした .

(注13) : 同時分布が与えられたときに, これと整合する一方の変数の分布は周辺分 布と呼ばれる

(注14)：符号化レート $R$ を持つ符号を用いて符号化を行うことを「レート $R$ で符 号化する」という.
をレート $H(Y)=\log _{2} 4$ で符号化すれば, 復号器は $(X, Y)$ を 誤りなく再生することができる(注15) $. X, Y$ の符号化レートの 和は $H(X)+H(Y)=\frac{1}{6} \log _{2} 12+\frac{1}{3} \log _{2} 6+\frac{3}{2} \log _{2} 4 \approx 4.459$ となる .

続いて, 符号器は情報源 $X$ と $Y$ の両方を観測して, 钅の相 関を利用して符号化してみよう.$X$ と $Y$ の両方が観測できると きは, 直積集合 $\mathcal{X} \times \mathcal{Y}$ の值を持つ一つの確率変数 $(X, Y)$ とみ なすことができるので, 前節の情報源符号化定理によれば, 以 下で定義される $(X, Y)$ の同時エントロピー

$$
H(X, Y)=\sum_{x \in \mathcal{X}} \sum_{y \in \mathcal{Y}} p_{X Y}(x, y) \log _{2} \frac{1}{p_{X Y}(x, y)}
$$

まで $(X, Y)$ の符号化レートを小さくできるはずである.実 際に，これを表 1 で与えられた同時分布 $p_{X Y}$ に適用すると， $H(X, Y)=\log _{2} 12 \approx 3.585$ となり, 最初の例より $(X, Y)$ の 符号化レートが小さくなっている (より圧縮できている) こと が分かる(注16).

続いて, 二つの符号器が情報源 $X$ と $Y$ の光れぞれ一方だけ を観測して，個別に符号化を行うことを考えよう．X, $Y$ を次 のように個別に符号化する. 以下では $X^{n}, Y^{n}, Z^{n}$ の $i$ 番目 の確率変数を光れ光れ $X_{i}, Y_{i}, Z_{i}$ とする.

- $X_{i}$ を 3 で割った余り，すなわち $Z_{i} \equiv X_{i} \bmod 3$ を 求め，これを繰り返して $Z^{n}$ を求める. 光して $Z^{n}$ をレート $\log _{2} 3$ で符号化する(注17). これを $X^{n}$ の符号語とする.

- $Y^{n}$ の出力は最初の方法と同じようにレート $\log _{2} 4$ で符 号化する.

$X^{n}$ と $Y^{n}$ の符号語を受信した復号器は次のように復号する .

- $X^{n}, Y^{n}$ の符号語から光れ光れ $Z^{n}, Y^{n}$ を再生する(注18).

- 各 $i$ に対して,$\left|X_{i}-Y_{i}\right| \leqq 1$ と $Z_{i}=X_{i} \bmod 3$ を同 時に満たす $X_{i}$ が $Y_{i}$ と $Z_{i}$ の値から唯一定まることから， $X_{i}$ を誤りなく特定できる．これを繰り返して $X^{n}$ を再生する． 以上の符号において, $(X, Y)$ の符号化レートは $\log _{2} 4+\log _{2} 3=$ $\log _{2} 12$ となる .

驚くべきことに, 最後の方法では二つの符号器が情報源 $X$ と $Y$ の光れ光れ一方だけを観測して個別に符号化を行ったにもか かわらず, 情報源 $X$ と $Y$ の両方を見て符号化を行った二番目 の方法と同じ性能を持つことが分かった .このようなことがで きる理由は, $X$ と $Y$ が $|X-Y| \leqq 1$ を満たすというある種 の相関を復号器が利用できたことにある.これを一般化すれば， $X$ と $Y$ の同時分布 $p_{X Y}$ を復号器が利用できれば, $X$ と $Y$ の 相関を利用した符号化が可能ということになる . 果してこのよ うなことは常に (任意の同時分布 $p_{X Y}$ に対して) 可能であろう

(注15)：X と $Y$ の周辺分布のエントロピーを定義式 (1) に当てはめて計算してみ よう.なお，この場合は $Y$ の出力 1 文字は $\log _{2} 4=2$ ビットで表現できること が分かるが, $X$ の出力 1 文字の符号化に必要なビット数には端数が出る. しかしな がら，直積集合 $\mathcal{X}^{n}$ で符号化を考えることにより端数を無視できるようになる． (注16) : 実際，表 1 の例で正の確率を持つ場合は 12 通りしかないので, $(X, Y)$ を $\log _{2} 12$ ビットで表現できるというのは自然であろう. (注17) : $Z_{i}$ は等確率分布になるので, $H\left(Z_{i}\right)=\log _{2} 3$ となる. (注18)： $X^{n}$ の符号語は $Z^{n}$ を符号化したものであることに注意 .なお， $Y$ は 4 通りの值しかとらず, $Z$ は 3 通りの值しかとらないことから, 常に正しく再生でき る方法があることが分かる 


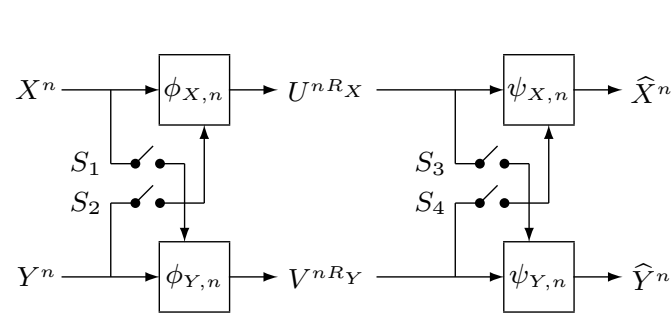

図 3 相関のある情報源符号化

か? 言い替えれば, Slepian-Wolf 符号が存在するための符号化 レートの条件はどのようなものだろうか? これを明らかにした のが Slepian-Wolf の定理である .

\section{3 Slepian-Wolf の定理}

Slepian-Wolf の論文 ${ }^{(5)}$ では, 二つの相関のある情報源の符

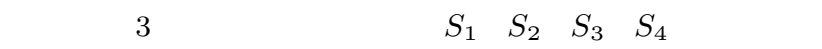
がオンとオフ の合計 16 通りの場合を考察している . 現在 Slepian-Wolf の定理として知られている図 1 の設定は , 図 3 に おいて $S_{1}, S_{2}$ がオフ $S_{3}, S_{4}$ がオンの場合である(注19). 前 節で解説したとおり，この定理の本質的なところは， $X^{n}$ と $Y^{n}$

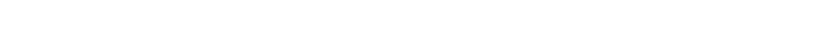
復号器が $X^{n}$ と $Y^{n}$ の相関 (同時分布) を利用するところにあ り，具体的な符号の構成は Shannon の情報源符号化定理（定理 1) から直ちに思いつくものではなさ光うだ .

以下に Slepian-Wolf の定理 ${ }^{(5)}$ を紹介する . 相関のある定常 無記憶情報源 $(X, Y)$ に対して, ブロック長 $n$ の出力系列 $X^{n}$, $Y^{n}$ の符号化レートを光れ光れ $R_{X}, R_{Y}$ とする.$X$ の符号 器を $\phi_{X, n}: \mathcal{X}^{n} \rightarrow\{0,1\}^{n R_{X}}, Y$ の符号器を $\phi_{Y, n}: \mathcal{Y}^{n} \rightarrow$ $\{0,1\}^{n R_{Y}}$, 復号器を $\psi_{n}:\{0,1\}^{n R_{X}} \times\{0,1\}^{n R_{Y}} \rightarrow \mathcal{X}^{n} \times \mathcal{Y}^{n}$ とする . 復号誤り確率は

$$
\operatorname{Prob}\left(\psi_{n}\left(\phi_{X, n}\left(X^{n}\right), \phi_{Y, n}\left(Y^{n}\right)\right) \neq\left(X^{n}, Y^{n}\right)\right)
$$

となる . 同時分布 $p_{X Y}$ が与えられたとき, 条件付確率分布 $p_{X \mid Y}$ は

$$
p_{X \mid Y}(x \mid y) \equiv \frac{p_{X Y}(x, y)}{\sum_{x \in \mathcal{X}} p_{X Y}(x, y)}
$$

となる. 条件付エントロピー $H(X \mid Y)$ を以下のように定義する .

$$
H(X \mid Y) \equiv \sum_{x \in \mathcal{X}} \sum_{y \in \mathcal{Y}} p_{X Y}(x, y) \log _{2} \frac{1}{p_{X \mid Y}(x \mid y)}
$$

同樣にして条件付確率分布 $p_{Y \mid X}$ と条件付エントロピー $H(Y \mid X)$ も定義できる．

定理 3 (順定理). 相関のある定常無記憶情報源 $(X, Y)$ に対し て，レート対 $\left(R_{X}, R_{Y}\right)$ が

$$
\begin{aligned}
& R_{X}>H(X \mid Y) \\
& R_{Y}>H(Y \mid X)
\end{aligned}
$$

(注19) $: S_{3}, S_{4}$ が オン の場合であることから，图 1 では現在の慣例にならい復 号器を一つにまとめている.

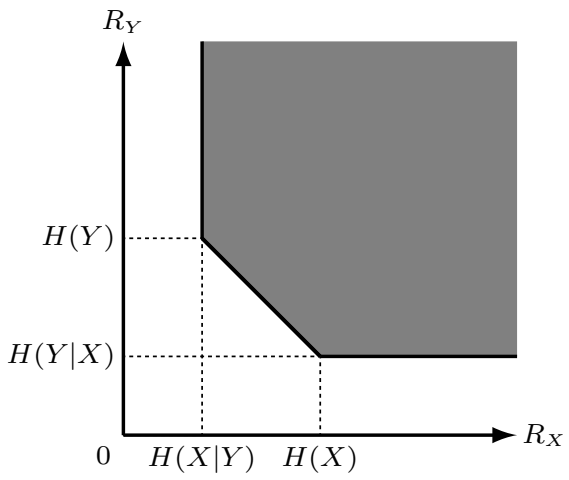

図 4 達成可能レート領域

$$
R_{X}+R_{Y}>H(X, Y)
$$

を満たせば(注20)，復号誤り確率が $n \rightarrow \infty$ とともに 0 に収束す るような符号 $\left\{\left(\phi_{X, n}, \phi_{Y, n}, \psi_{n}\right)\right\}_{n=1}^{\infty}$ が存在する.

定理 4 (逆定理). 相関のある定常無記憶情報源 $(X, Y)$ に対し て , 復号誤り確率が $n \rightarrow \infty$ とともに 0 に収束するような符号 $\left\{\left(\phi_{X, n}, \phi_{Y, n}, \psi_{n}\right)\right\}_{n=1}^{\infty}$ のレート対 $\left(R_{X}, R_{Y}\right)$ は

$$
\begin{array}{r}
R_{X} \geqq H(X \mid Y) \\
R_{Y} \geqq H(Y \mid X) \\
R_{X}+R_{Y} \geqq H(X, Y)
\end{array}
$$

を満たしている．

図 4 の塗りつぶされた領域は（7）〜（9）の不等式を満た す $\left(R_{X}, R_{Y}\right)$ の全体からなる集合である . ここで, 順定理では $n \rightarrow \infty$ として $\left(R_{X}, R_{Y}\right)$ をこの領域の境界に限りなく近い符 号化レートを持つ符号が存在するとみなしてもよい . 以下では， この集合を（達成可能）レート領域と呼ぶ．なお，これまでは 復号誤り確率が限りなく小さい符号を導入したが, 復号誤り確 率が真に 0 となるような符号に関しては Slepian-Wolf の定理 が一般には成立しないことが示されている(9). これは, 情報源

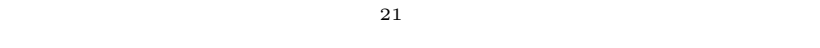
率が真に 0 となるような符号を構成できる点と大きく異なる点 である(注22) 。

(注20)：本稿の基になった解説論文 ${ }^{(57)}$ では, 条件式 (7) 〜 (9) を必要十分条件 として紹介してしまっているが, これは厳密ではない, 必要十分条件を述べたい場合 は,「条件 (7) 〜 (9) を満たす $\left(R_{X}, R_{Y}\right)$ に限りなく近い符号化レート対を持つ 符号が存在する」とすべきであった .

(注21) : 符号語の長さが圧縮対象の系列に依存して異なっていることを許す符号． (注22)：一般に成立しないとは, 式 (7) 〜 (9) で定まる領域の全てで復号誤り確 率が真に 0 の Slepian-Wolf 符号が存在するとは限らないことを意味する.例え ばそれ光れの符号器が $(X, Y)$ の両方を見ることができれば, Huffman 符号や算 術符号などの復号誤りが全く起こらないように設計された符号を用いて, トータルの レートが $H(X, Y)$ となる可变長符号を構成できる.しかしながら, Slepian-Wolf 符号では一方の情報源の符号器が他方の情報源の出力を観測できないので，この方法 は認められない . 


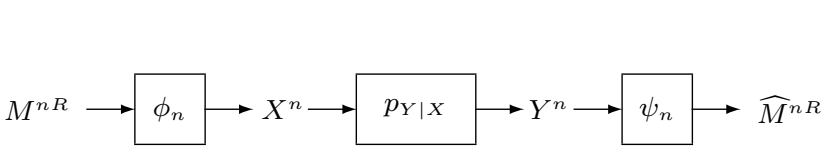

図 5 通信路符号化

\section{通信路符号から Slepian-Wolf 符号}

ここから順定理の証明手法の変遷を追いかけたいと思う． Slepian-Wolf の論文 ${ }^{(5)}$ にある証明は通信路容量を達成する通信 路符号を利用したものである. 弚こでまず, 通信路符号の復習 をしたい。

\section{1 通信路符号化定理}

通信路に $X^{n}$ を入力したとき, 杂隹音が加わつた出力 $Y^{n}$ が 得られる.これを $X^{n}$ から $Y^{n}$ に遷移する確率 (条件付確率) $p_{Y \mid X}$ で特徵付ける. 通信路符号化では, 符号器はメッセージ $M^{n R}$ を符号化した符号語 $X^{n}$ を通信路入力とし, 復号器は通 信路出力 $Y^{n}$ から元のメッセージを復号して 0 に近い復号誤り 確率で再生することを試みる (図 5 ) .ここで， $R>0$ は通信路 の単位入力長に対して何ビットのメッセージを正しく送ることが できるかを示す量で符号化レートと呼ばれている． $R$ が大きい ほど性能の良い符号ということになる . 形式的には , 符号器は関 数 $\phi_{n}:\{0,1\}^{n R} \rightarrow \mathcal{X}^{n}$, 復号器は関数 $\psi_{n}: \mathcal{Y}^{n} \rightarrow\{0,1\}^{n R}$ と表現することができる(注23). 復号誤り確率は

$$
\operatorname{Prob}\left(\psi_{n}\left(Y^{n}\right) \neq M^{n R}\right)
$$

となる(注24)

Shannon は情報理論に関する最初の論文 ${ }^{(1)}$ で次の定理を証 明した . $C$ を次のように定義する(注25).

$$
C \equiv \max _{X}[H(X)-H(X \mid Y)]
$$

定理 5 (順定理). 符号化レート $R$ が $R<C$ を満たすとき， 復号誤り確率が $n \rightarrow \infty$ とともに 0 に収束するような符号 $\left\{\left(\phi_{n}, \psi_{n}\right)\right\}_{n=1}^{\infty}$ が存在する .

定理 6 (逆定理). 復号誤り確率が $n \rightarrow \infty$ とともに 0 に収束 するような全ての符号 $\left\{\left(\phi_{n}, \psi_{n}\right)\right\}_{n=1}^{\infty}$ は $R \leqq C$ を満たして いる

ここで, 通信路の条件付確率から定まる量 $C$ は通信路容量 と呼ばれている．なお，現在の標準的な教科書では相互情報量 $I(X ; Y) \equiv H(X)-H(X \mid Y)$ を定義 (主26) して通信路容量を

(注23) $: n R$ が整数でない場合は切り捨てが必要であるが, $n \rightarrow \infty$ とともに符号 化レートへの影響を無視することができる

(注24)： $\phi_{n}$ や $X^{n}$ が登場しないことを奇妙に思うかも知れないが, $X^{n}$ が $M^{n R}$ と $\phi_{n}$ に依存し, $Y^{n}$ が $X^{n}$ に依存していることに注意してほしい.

(注25) : $\max _{X}$ は入力分布 $p_{X}$ を動かしたときの最大值を表す. 条件付き確率と入 力分布が与えられれば, $(X, Y)$ の同時確率が定まるので $[H(X)-H(X \mid Y)]$ か計 算できる . 通信路入力は $\max _{X}$ で最適化されるので, $\max _{X}[H(X)-H(X \mid Y)]$ は条件付き確率だけで定まる量である

(注26)：相互情報量を導入したのは Fano であることを Princeton 大学の Verdú 先生から教えて頂いた。
表 2 メッセージと符号語の対応: $n=4, n R=2$ の 場合. 右欄は $p_{X}$ に従って独立かつランダムに 生成する.

\begin{tabular}{|c|c|}
\hline メッセージ & 符号語 (通信路入力) \\
\hline 00 & 1010 \\
\hline 01 & 0110 \\
\hline 10 & 1001 \\
\hline 11 & 0101 \\
\hline
\end{tabular}

$\max _{X} I(X ; Y)$ と書くことが多い.ここでは Shannon の最初 の論文 ${ }^{(1)}$ にならい $\max _{X}[H(X)-H(X \mid Y)]$ と書いた .あえて こう表記したのは後の説明の伏線になっている .

最初の定理では , $n \rightarrow \infty, R \rightarrow \max _{X}[H(X)-H(X \mid Y)]$ とすることにより，通信路容量に限りなく近い符号化レートを 持つ符号が存在するとみなしてもよい. 以上の定理から, 通信 路容量が符号化レートの限界であると結論付けることができた . ここで, 通信路符号化定理の順定理の証明の要点も復習させ て頂きたい. Slepian-Wolf の証明を理解するためには, これも 欠かすことができない，まず, 符号器の設計のために, 確率 $p_{X}$ で独立に発生させた長さ $n$ の系列 ( $\mathcal{X}^{n}$ の要素) を $2^{n R}$ 個用意 する.これらと $2^{n R}$ 個のメッセージを 1 対 1 対応させたテー ブル (表 2) を用意し，これを符号器と復号器で共有しておく. メッセージと対応させた $\mathcal{X}^{n}$ の要素 (表 2 の右欄に書かれた系 列) が符号語になる. 同時典型集合 $\mathcal{T}_{X Y, \varepsilon}^{n} \subset \mathcal{X}^{n} \times \mathcal{Y}^{n}$ を次の ように定義する．

$$
\begin{aligned}
& \left.\mathcal{T}_{X Y, \varepsilon}^{n} \quad \begin{array}{rl}
\left|\frac{1}{n} \log _{2} \frac{1}{p_{X Y}\left(x^{n}, y^{n}\right)}-H(X, Y)\right| \leqq \varepsilon \\
\left(x^{n}, y^{n}\right):\left|\frac{1}{n} \log _{2} \frac{1}{p_{X \mid Y}\left(x^{n} \mid y^{n}\right)}-H(X \mid Y)\right| \leqq \varepsilon \\
\left|\frac{1}{n} \log _{2} \frac{1}{p_{Y \mid X}\left(y^{n} \mid x^{n}\right)}-H(Y \mid X)\right| \leqq \varepsilon
\end{array}\right\}
\end{aligned}
$$

符号器と復号器の構成は以下のとおり.

・ 符号器はテーブルを参照してメッセージ $m^{n R}$ と対応す る符号語を通信路に入力する. 符号器 $\phi_{n}$ は以下のようになる.

$$
\phi_{n}\left(m^{n R}\right) \equiv\left[m^{n R} \text { と対応する符号語 }\right]
$$

- 復号器は受信した $Y^{n}$ から, $\left(\widehat{x}^{n}, Y^{n}\right)$ が同時典型集合に 属しているような $\widehat{x}^{n}$ を符号語をテーブルから探し，対応する メッセージを再生する . 復号器 $\psi_{n}$ は以下のようになる .

$$
\begin{aligned}
& \psi_{n}\left(y^{n}\right) \\
& \equiv\left[\begin{array}{l}
\text { 受信した } y^{n} \text { に対して }, \\
\left(\widehat{x}^{n}, y^{n}\right) \in \mathcal{T}_{X Y, \varepsilon}^{n} \text { となる } \widehat{x}^{n} \text { を符号語集合から探し }, \\
\text { これと対応するメッセージを再生する . } \\
\text { とのような } \widehat{x}^{n} \text { が存在しない , } \\
\text { あるいは二つ以上存在するときは復号誤りとする . }
\end{array}\right]
\end{aligned}
$$

このような復号法は典型集合復号と呼ばれている . 


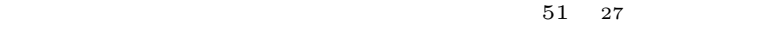
が, $R<H(X)-H(X \mid Y)$ を満たせば , すなわち $\varepsilon>0$ に対 してテーブルとして用意した符号語の数が $2^{n[H(X)-H(X \mid Y)-\varepsilon]}$ 以下であれば , 復号誤り確率が 0 に収束するようにテーブルを 作ることができる．ここで, $\max _{X}[H(X)-H(X \mid Y)]$ を達成 する $X$ を取ることにより，構成した符号は通信路容量を達成す る. Slepian-Wolf の証明のために覚えておいて頂きたいのは， $\mathcal{X}^{n}$ の要素を $p_{X}$ に従って $2^{n[H(X)-H(X \mid Y)-\varepsilon]}$ 個発生させた テーブルを用意することにより，復号誤り確率が 0 に近づく通 信路符号を構成できることである．

\section{2 Slepian-Wolf の証明}

いよいよここから Slepian-Wolf による順定理の証明 ${ }^{(5)}$ を解 説する

彼らの論文では, 最初に $Y^{n}$ をレート $H(Y)$ 付近で符号化し たときに $X^{n}$ をレート $H(X \mid Y)$ 付近で符号化できることを示 した .これは, 図 4 において $(H(X \mid Y), H(Y))$ 付近のレート 対を達成する符号を構成することと対応する．続いて，時分割 原理と呼ばれている方法を用いてレート領域にある全てのレー 卜対を達成できることを示した .

ここで，時分割原理について簡単に説明しておこう. $(H(X \mid Y), H(Y))$ 付近のレート対を達成する符号を構成で きれば，同樣にして $(H(X), H(Y \mid Y))$ 付近のレート対を達 成する符号を構成できる(注28). 符号化では, 最初に長さ $N$ のブロックを長さ $n$ のサブブロックに分割する . 乥して幾 つかのサブブロックは $(H(X \mid Y), H(Y))$ 付近のレート対で， 残りのサブブロックは $(H(X), H(Y \mid Y))$ 付近のレート対で 符号化する.長さ $N$ のブロックの復号では, サブブロック ごとに対応する復号器を用いれば誤り確率が 0 に近い復号 ができるはずである(注29). どちらの符号器を使うかの混合比 を $\theta \in[0,1]$ とすれば，長さ $N$ のブロックのレート対は $(\theta H(X \mid Y)+[1-\theta] H(X), \theta H(Y)+[1-\theta] H(Y \mid X))$ となる.す なわち, 図 4 において $(H(X \mid Y), H(Y))$ と $(H(X), H(Y \mid Y))$ の任意の内分点 (斜線の境界線上) のレート対を持つ符号が構 成できることになる. 図 4 のほかの領域内にあるほかのレート 対を持つ符号の存在については, わざと冗長に符号化すればよ いので自明であり，これで Slepian-Wolf の順定理か証明できた ことになる .

それでは $(H(X \mid Y), H(Y))$ 付近のレート対を達成する符号 を構成する．情報源符号化定理 (定理 1) から， $Y^{n}$ はレート $[H(Y)+\varepsilon]$ の符号を用いれば 0 に近い復号誤り確率で復号でき るので, 復号器は $Y^{n}$ を直接観測できると考えても差し支えない (図 6) .この場合， $Y^{n}$ は $X^{n}$ を再生するための補助情報と呼ば れるものになる . Slepian-Wolf の論文では , $(H(X \mid Y), H(Y))$

(注 27 ) : 同時典型集合の定義が教科書 ${ }^{(51)}$ のものと異なっているが, 本質的な違いと はならない

(注28)： $X^{n}$ をレート $H(X)$ 付近で符号化した時に $Y^{n}$ をレート $H(Y \mid X)$ 付 近で符号化する.

(注29)：もちろん, サブブロックをどちらの符号器で符号化したかを事前に復号器 に知らせておく必要がある.

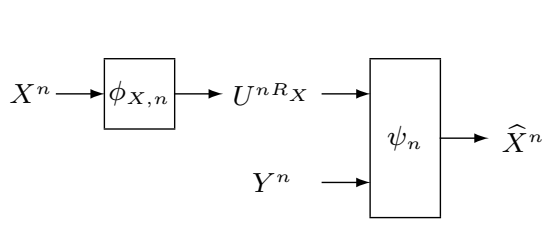

図 6 補助情報 $Y^{n}$ を伴う情報源 $X^{n}$ の符号化

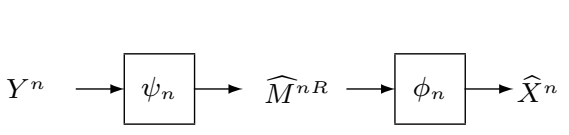

図 7 通信路符号を改造してみる

付近のレート対を達成する符号を構成するために，相関のある 情報源 $\left(X^{n}, Y^{n}\right)$ を入力 $X^{n}$ 出力 $Y^{n}$ の通信路とみなして，こ の通信路に対する符号を考えた。

図 7 において, 図 5 の復号器 $\psi_{n}$ の後に図 5 の符号器 $\phi_{n}$ を 連結した合成関数 $\phi_{n} \circ \psi_{n}$ は, 補助情報 $Y^{n}$ から情報源 $X^{n}$ を再生しているように見える.この合成関数を図 6 の復号器 $\psi_{n}$ の構成に利用しよう．ここで, 通信路符号化定理より， $Y^{n}$ から 誤りなく再生できる $X^{n}$ は高々 $2^{n[H(X)-H(X \mid Y)-\varepsilon]}$ 個であつ たことを思い出してほしい．－一方で 2.1 の情報源符号化定理の 順定理の証明で説明したように， $X^{n}$ を 0 に近い復号誤り確率 で復号するためには $2^{n[H(X)+\varepsilon]}$ 個の要素から成る典型集合を 0 に近い復号誤り確率で復号できるようにしたい．どうすれば よいだろうか?

Slepian-Wolf の論文では, $2^{n[H(X)-H(X \mid Y)-\varepsilon]}$ 個の符号語 集合を持つ通信路符号を，符号語集合が互いに素になるよう に $2^{n[H(X \mid Y)+2 \varepsilon]}$ 個用意した ここれにより 1 に近い確率を持 つ高々 $2^{n[H(X \mid Y)+2 \varepsilon]} 2^{n[H(X)-H(X \mid Y)-\varepsilon]}=2^{n[H(X)+\varepsilon]}$ 個の $X^{n}$ の部分集合を, 用意した符号語全体でカバーできる . 用意し た符号語集合には $n R_{X} \equiv n[H(X \mid Y)+2 \varepsilon]$ ビットのインデッ クスを付与しておく. 符号器は, $X^{n}$ が属する符号語集合があ ればそのインデックスを符号語とする.なければ $0^{n R_{X}}$ を符号 語とする. 符号化レートは $R_{X}=H(X \mid Y)+2 \varepsilon$ になる . 一 方で, 良い通信路符号はうまく選んだ $2^{n[H(X)-H(X \mid Y)-\varepsilon]}$ 個 の $X^{n}$ の出力系列を $Y^{n}$ から誤りなく復元できるので, 復号 器はレート $R_{X}=H(X \mid Y)+2 \varepsilon$ のインデックスにより符号 語集合を定め, $Y^{n}$ からこの符号語集合の要素の一つを特定す ることにより $X^{n}$ を誤りなく復号できる．以上によりレート $R_{X}=H(X \mid Y)+2 \varepsilon$ を持つ符号が構成できることが分かった . $\varepsilon \rightarrow 0$ とすることにより, $(H(X \mid Y), H(Y))$ に限りなく近い レート対を持つ Slepian-Wolf 符号の存在が示される.

ここで, Slepian-Wolf の証明にある $(H(X \mid Y), H(Y))$ 付近 のレート対を達成する符号の構成をまとめておく. $u^{n R_{X}}, v^{n R_{Y}}$ を光れ光れ $x^{n}$ の符号語, $y^{n}$ の符号語とする.

$X^{n}$ の符号器:

$\phi_{X, n}\left(x^{n}\right) \equiv\left\{\begin{array}{l}{\left[x^{n} \text { を含む符号語集合のインデックス }\right]} \\ 0^{n R_{X}}\left(x^{n} \text { を含む符号語集合がないとき }\right)\end{array}\right.$ 
$Y^{n}$ の符号器:

$\phi_{Y, n}\left(y^{n}\right) \equiv\left[\begin{array}{l}\text { レート } H(Y) \text { 付近の情報源符号を用いて } \\ y^{n} \text { を符号化 . }\end{array}\right]$

復号器:

$$
\begin{aligned}
& \psi_{n}\left(u^{n R_{X}}, v^{n R_{Y}}\right) \\
& \equiv\left[\begin{array}{l}
\phi_{Y, n} \text { と対応する復号器を用いて } \\
v^{n R_{Y}} \text { から } \widehat{y}^{n} \text { を再生し }, \\
\text { インデックス } u^{n R_{X}} \text { を持つ通信路符号を用いて } \\
\widehat{y}^{n} \text { から } \widehat{x}^{n} \text { を再生 . }
\end{array}\right]
\end{aligned}
$$

以上が Slepian-Wolf の論文の証明の概略であるが , 符号語 集合が互いに素になるように複数の通信路符号を用意できるの か, 更に乥れらの和集合が確率 1 に近い集合を形成しているの かなど，証明を工夫し精密に議論しなければならないところが 残されている．これらの詳細は Slepian-Wolf の論文を確認し てほしい.なお, 文献(12)では, Slepian-Wolf と同樣の典型集 合の議論により, 式 $(4) \sim(6)$ を満たす任意の $\left(R_{X}, R_{Y}\right)$ を レートに持つ Slepian-Wolf 符号を, 時分割原理の議論を経ず に直接構成している.

\section{3 Wyner の証明}

後になって, $X$ が一樣分布を持ち, $X, Y$ が二元対称通信

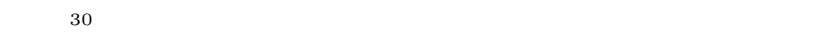
一つの線形符号 (パリティ検査行列) を用いて前節の「互いに素 な符号語集合を持つ複数の通信路符号」を実現することにより Slepian-Wolf 符号を構成できることが Wyner ${ }^{(7)}$ にっって示さ れた (注31).

まず, 線形符号について復習させて頂きたい . 線形符号は, 図 5 の通信路符号化において, 符号語集合

$$
\left\{\phi_{n}\left(m^{n R}\right): m^{n R} \in\{0,1\}^{n R}\right\}
$$

が線形空間を成す符号である . 一つの線形符号の符号語集合は $n[1-R] \times n$ パリティ検査行列 $A$ を用いて次のように記述で きる注32) .

$$
\left\{x^{n}: A x^{n}=0^{n[1-R]}\right\}
$$

このとき, 符号器となる $n \times n R$ 生成行列 $G$ が存在して, メッ セージを表す $n R$ 次元の列ベクトル $m^{n R}$ の符号語（通信路入 力) は $n$ 次元のベクトル $G m^{n R}$ となる.つまり，符号器を有 限体上の線形写像で与えることができる . 復号器では , 符号語 集合 $\left(A x^{n}=0^{n[1-R]}\right.$ を満たす $\left.x^{n}\right)$ の中から受信系列 $Y^{n}$ と

(注30) : $X=0$ が $Y=1$ となる確率と $X=1$ が $Y=0$ となる確率が等しい 通信路. 入力 $X$ とは独立な雑音 $Z \in\{0,1\}$ を用いて $Y=X+Z$ と書けるの で, 二元加法的通信路とも呼ばれる

(注31) : 電気通信大学の森田先生のお話では, Cornell 大学の Berger 先生も同 樣の考えを持っていたようである

(注32) : 符号理論の標準的な教科書ではパリティ検査行列として $H$ が用いられるこ とが多いが, エントロピーの $H$ と混同しないために $A$ と表記した .

$$
p_{X \mid Y}\left(x^{n} \mid y^{n}\right) \equiv \frac{p_{Y \mid X}\left(y^{n} \mid x^{n}\right) p_{X}\left(x^{n}\right)}{\sum_{x^{n} \in \mathcal{X}^{n}} p_{Y \mid X}\left(y^{n} \mid x^{n}\right) p_{X}\left(x^{n}\right)}
$$

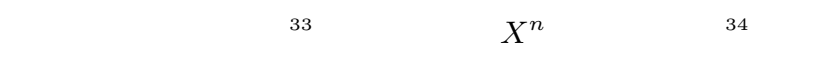
れより元のメッセージを再生する(注35).このように, ある条件 下で確率を最大にする系列を求める復号法は最ゆう復号と呼ば れている. Elias は次の補題を証明した ${ }^{(2)}$.

補題 2. 通信路が二元対称通信路で, $X$ が一樣分布を持つとき， $R<1-H(X \mid Y)$ を満たせば, $n[1-R] \times n$ パリティ検査行 列 $A$ が存在して， $A$ を用いた線形符号の復号誤り確率を 0 に 十分近くできる .

$X, Y$ が二元対称通信路の入出力であるとき, $X$ を一樣分 布の確率変数（すなわち $H(X)=1$ ) としたときに通信路容量 $1-H(X \mid Y)$ を達成する.したがって, 通信路が二元対称通信 路のときは線形符号により通信路容量を達成できる .

ここで, パリティ検査行列 $A$ が定まれば, 集合 $\mathcal{X}^{n}$ はベクト ル $c^{n[1-R]}$ によって定まるコセット

$$
\mathcal{C}_{A}\left(c^{n[1-R]}\right) \equiv\left\{x^{n}: A x^{n}=c^{n[1-R]}\right\}
$$

によって互いに素な $2^{n[1-R]}$ 個の集合に分割される(注36) こと に注目しよう .コセットを定める $c^{n[1-R]}$ はシンドロームと呼 ばれているものである.コセット $\mathcal{C}_{A}\left(c^{n[1-R]}\right)$ を符号語集合 とする符号はコセット符号と呼ばれている . 前述の線形符号は $\mathcal{C}_{A}\left(0^{n[1-R]}\right)$ と書けるのでコセット符号の一つである .

Wyner の証明では, 通信路符号のレートを $R=1-$ $H(X \mid Y)-\varepsilon$ と置き, $n[H(X \mid Y)+\varepsilon] \times n$ パリティ検査行 列 $A$ を用いて Slepian-Wolf 符号を構成する. 具体的には, 系 列 $X^{n}$ にパリティ検査行列を作用させたシンドローム $A X^{n}$ を光 の符号語とすることによって, $(H(X \mid Y), H(Y))$ 付近のレート 対を達成する符号を構成する. 異なるシンドロームと対応するコ セットは互いに素になるという性質があったので, Slepian-Wolf の証明と同じ議論ができることになる .ここで, 線形符号の説 明の途中で $X^{n}$ を小さい復号誤り確率で再生できると書いたが， $X^{n}$ の再生と同時に差分(注37) $Z^{n} \equiv Y^{n}-X^{n}$ も小さい復号誤 り確率で再生できていることに注目しよう. Slepian-Wolf 符号 の復号器は符号語 $A X^{n}$ と $Y^{n}$ を受信することにより

$$
A Z^{n}=A\left[Y^{n}-X^{n}\right]=A Y^{n}-A X^{n}
$$

を用いて $Z^{n}$ のシンドロームを得る .これから $Z^{n}$ を 0 に近い 復号誤り確率で再生することができる (注38). したがって, 再生

(注33) : 通信路の条件付確率 $p_{Y \mid X}$ と入力分布 $p_{X}$ だけがあらかじめ与えられて いることに注意しよう

(注 34 ) : 反転確率が $1 / 2$ 末満の場合は, $Y^{n}$ とのハミング距離 (シンボルが異なる 成分の数) が最も小さい符号語を求めることと同じである.これは最小距離復号と呼 ばれる. Elias の論文 ${ }^{(2)}$ では補題 2 の証明において最小距離復号を採用していた . (注35) : $x^{n}$ から元のメッセージを再生することは線形操作 (行列を作用させるこ と) で実現できる。

(注 36) : 行列 $A$ がフルランクの行列でない場合はコセットの数は少なくなるのだ が , 以降の議論では $A$ はフルランクになっていると仮定する (注37) : $X^{n}$ と $Y^{n}$ が通信路の入出力の場合は雑音とも呼ばれる

(注38) : $A X^{n} \neq 0^{n[1-R]}$ の場合にもこの事実が正しいことは自明ではないと思う が, 通信路の対称性より全てのコセット符号の復号誤り確率が等しいことが言えるの で, $A X^{n}=0^{n[1-R]}$ の場合に復号誤り確率が 0 に近ければ, $A X^{n} \neq 0^{n[1-R]}$ の場合にも復号誤り確率が 0 に近くなる.これについては 4.5 でも補足する. 
した $Z^{n}$ から $X^{n}=Y^{n}-Z^{n}$ によって $X^{n}$ を再生できること になる ・

ここで, Wyner の証明にある符号の構成をまとめておく .

$X^{n}$ の符号器: $\phi_{X, n}\left(x^{n}\right) \equiv A x^{n}$.

$Y^{n}$ の符号器:

$\phi_{Y, n}\left(y^{n}\right) \equiv\left[\begin{array}{l}\text { レート } H(Y) \text { 付近の情報源符号を用いて } \\ y^{n} \text { を符号化 . }\end{array}\right]$

復号器:

$\psi_{n}\left(u^{n R_{X}}, v^{n R_{Y}}\right)$

$\equiv\left[\begin{array}{l}\phi_{Y, n} \text { と対応する復号器を用いて } \\ v^{n R_{Y}} \text { から } \widehat{y}^{n} \text { を再生し }, \\ \text { シンドローム }\left[A \widehat{y}^{n}-u^{n R_{X}}\right] \text { から杂隹音 } \widehat{z}^{n} \text { を再生する. } \\ \text { として } \widehat{x}^{n} \equiv \widehat{y}^{n}-\widehat{z}^{n} \text { とする. }\end{array}\right]$

Wyner のアイデアを実現するには，通信路容量に近いレー 卜を持つ線形符号を必要とする．弚のような符号は実現が困難 であると考えられていたのだが, ターボ符号 ${ }^{(17)}$, LDPC (Low Density Parity Check) 符号 ${ }^{(3)}$, ポーラ符号 ${ }^{(43)}$ など, 通信路 容量に近いレートを持つ線形符号で復号処理が実用的な時間で実

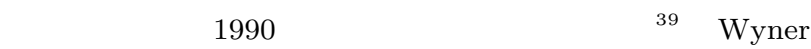
のアイデアとこれらのアイデアを組み合わせた Slepian-Wolf 符 号の構成が文献(23)，(27)，(28)，(42) で提案されている.

ここで, このように提案された符号はいずれも，Xが一樣分 布を持ち， $X, Y$ が二元対称通信路の入出力となるような相関 を有する情報源に限定することにより，(H(X|Y),H(Y)) 付近 のレート対を達成したことを強調しておきたい．

\section{Random Binning}

Slepian-Wolf による証明は通信路符号を利用したものであ り，回りくどく複雑であった . 1975 年に Cover ${ }^{(8)}$ は, random binning と呼ばれる手法を用いて時分割原理の議論を用いず にレート領域にある全てのレート対を達成できる符号を構成し， Slepian-Wolf の定理を相関のある定常エルゴード情報源の場合 に拡張した . 更に Cover はこの方法を用いて , 相関のある情報 源が 3 個以上ある場合のレート領域を決定している .このアイ デアによって, Slepian-Wolf の定理の証明が見通しの良いもの となり，多端子情報理論の重要なツールとなっている．

\section{1 Random Binning とは}

Cover の random binning では, $\mathcal{X}^{n}$ の系列を納めるために $2^{n R_{X}}$ 個の箱 (bin) を用意して, 各系列をいずれかの箱に独立 かつ等確率でランダムに入れてゆく. 乥して，箱とインデックス

(注39) : ターボ符号を線形符号とみなすことができることは文献(20) で言及されて いる.また LDPC 符号は Gallagar が提案したものが 1990 年代に再発見され た(20).
表 3 符号語と箱の中身: $n=4, n R_{X}=2$ の場合。 $\mathcal{X}^{n}$ の各要素を独立かつ等確率でいずれかの箱 に入れる.

\begin{tabular}{|c|c|}
\hline 符号語 & 箱の中身 \\
\hline 00 & $0000,0101,1010,1111$ \\
\hline 01 & $0010,0111,1000,1101$ \\
\hline 10 & $0001,0100,1011,1110$ \\
\hline 11 & $0011,0110,1001,1100$ \\
\hline
\end{tabular}

の対応を定めたテーブル (表 $3^{\text {(注40) }}$ ) をあらかじめ符号器と復 号器で共有しておく. $\mathcal{Y}^{n}$ に関しても同樣に $2^{n R_{Y}}$ 個の箱とイ ンデックスの対応を定めた表を符号器と復号器で共有しておく.

$X^{n}$ の符号器は, テーブルを参照して $X^{n}$ を含む箱のインデッ クスを符号語とする . テーブルを関数 $A: \mathcal{X}^{n} \rightarrow\{0,1\}^{n R_{X}}$ と 表せば，符号語は $A x^{n}$ となる(注41) . 同樣に， $Y^{n}$ の符号器は， テーブルを参照して $Y^{n}$ を含む箱のインデックスを符号語とす る. テーブルを関数 $B: \mathcal{Y}^{n} \rightarrow\{0,1\}^{n R_{Y}}$ と表せば , 符号語は $B y^{n}$ となる.

一方で，二つの符号語 $u^{n R_{X}}, v^{n R_{Y}}$ を受信した復号器は， $X^{n} \in\left\{x^{n}: A x^{n}=u^{n R_{X}}\right\}, Y^{n} \in\left\{y^{n}: B y^{n}=v^{n R_{Y}}\right\}$ であ ることが分かる.ここから $\left(X^{n}, Y^{n}\right)$ を再生するために, 典型 集合復号を行う. すなわち $,\left(\widehat{x}^{n}, \widehat{y}^{n}\right) \in \mathcal{T}_{X Y, \varepsilon}^{n}, A \widehat{x}^{n}=u^{n R_{X}}$, $B \widehat{y}^{n}=v^{n R_{Y}}$ を同時に満たすぺア $\left(\widehat{x}^{n}, \widehat{y}^{n}\right)$ を求めて再生語 とする.ここで， $\mathcal{T}_{X Y, \varepsilon}^{n}$ は式 (10) で定義した同時典型集合で ある・

ここで, random binning による符号の構成をまとめておく.

$$
\begin{aligned}
& X^{n} \text { の符号器: } \phi_{X, n}\left(x^{n}\right) \equiv A x^{n} . \\
& Y^{n} \text { の符号器: } \phi_{Y, n}\left(y^{n}\right) \equiv B y^{n} . \\
& \text { 復号器: } \\
& \psi_{n}\left(u^{n R_{X}}, v^{n R_{Y}}\right) \\
& \equiv\left[\begin{array}{l}
\left(\widehat{x}^{n}, \widehat{y}^{n}\right) \in \mathcal{T}_{X Y, \varepsilon}^{n}, A \widehat{x}^{n}=u^{n R_{X}}, B \widehat{y}^{n}=v^{n R_{Y}} \\
\text { を同時に満たす }\left(\widehat{x}^{n}, \widehat{y}^{n}\right) \text { を再生する } . \\
\text { 产ような }\left(\widehat{x}^{n}, \widehat{y}^{n}\right) \text { が存在しない }, \\
\text { あるいは二つ以上存在するときは復号誤りとする } .
\end{array}\right.
\end{aligned}
$$

Cover は $\mathcal{X}^{n}$ の全ての要素をいずれかの箱に独立かつ等確 率でランダムに入れてゆくという方法で random binning を構 成した . random binning の方法はユニバーサル符号 ${ }^{\left(\text {注 }^{42}\right)}$ の解 析の際に用いられた ${ }^{(15)}$. またこの方法は相関のある一般情報

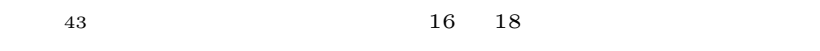
して示された Han の補題 ${ }^{(18)}$ が, Slepian-Wolf 符号の有限長

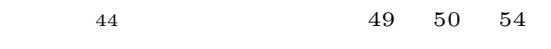

(注40) : 全ての箱の中身が同じ個数になるような表になっているが , ここでは同じ 個数にならない場合もある

(注41)：A は線形写像とは限らないが, 線形の場合も含めて統一的に結果を述べる ために $A x^{n}$ と記すことにする

(注 42$)$ : 固定されたレート対 $\left(R_{X}, R_{Y}\right)$ を持つ符号で, 式 $(4) \sim(6)$ を満たす 任意の $(X, Y)$ で誤り確率が 0 に収束するもの.

(注43)：確率分布の定常性や独立性を一切仮定しない情報源 .

(注44) : $n$ が比較的小さいときに,レートの限界にどこまで近い符号長を達成でき るかを求めること. 
これで Slepian-Wolf の順定理が証明できることは， Csiszár ${ }^{(14)}$ による線形写像を用いた方法を説明した後に述べ たい.

\section{2 線形写像による Random Binning}

Cover の random binning は, $\mathcal{X}^{n}$ から $\{0,1\}^{n R_{X}}$ への全 ての写像の集合から一つの写像を等確率でランダムに選択する ことと対応する. Csiszár ${ }^{(14)}$ は線形写像全体から一つの写像を 等確率でランダムに一つ選択することを考えた．乥して，線形 写像による定常無記憶情報源に対する固定長ユニバーサル符号 の存在を証明した .

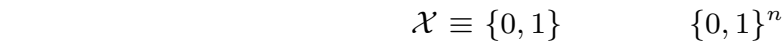
から $\{0,1\}^{n R_{X}}$ への線形写像を考える(注45). これは, $n R_{X} \times n$ 行列で表現できるので, 表 3 のようなテーブルを共有する代わ りに, $n^{2} R_{X}$ 個の 0,1 で表現された行列を共有するだけで十分 となる．また符号化の計算複雑度も $O\left(n^{2}\right)$ にできる.

箱 (bin) と対応する符号語は, 系列に行列を作用させた值 (シンドローム) と対応する.すなわち，系列は行列とシンド ロームより定まる箱 (コセット) のいずれかに収納されている と解釈できる．実は，表 3 は

$$
A \equiv\left(\begin{array}{cccc}
0 & 1 & 0 & 1 \\
1 & 0 & 1 & 0
\end{array}\right)
$$

を用いて $A x^{n}$ によって $x^{n}$ を入れる箱 (符号語) を決定したと きのテーブルと一致していた . 典型集合復号を採用することに より，関数 $A, B$ が線形性を持つこと以外は前節で説明した構 成と全く同じにすることもできるが，ここでは最ゆう復号を用 いた符号の構成を与えておく(注46).

$$
\begin{aligned}
& X^{n} \text { の符号器: } \phi_{X, n}\left(x^{n}\right) \equiv A x^{n} . \\
& Y^{n} \text { の符号器: } \phi_{Y, n}\left(y^{n}\right) \equiv B y^{n} . \\
& \text { 復号器: } \psi_{n}\left(u^{n R_{X}}, v^{n R_{Y}}\right) \equiv \arg \max _{\substack{\left(\widehat{x}^{n}, \widehat{y}^{n}\right): \\
A \widehat{x}^{n}=u^{n R_{X}} \\
B \widehat{y}^{n}=v^{n R_{Y}}}} p_{X Y}\left(\widehat{x}^{n}, \widehat{y}^{n}\right) .
\end{aligned}
$$

Csiszár ${ }^{(14)}$ は写像を有限体上の線形写像全体から選択してい たが, 行列として疎行列 (LDPC 行列) を用いてもレート領域 内の全てのレート対で Slepian-Wolf 符号を構成できることが示 されている(36)，(47). また LDPC 行列を用いた Slepian-Wolf 符号の統計力学的な解析が文献 (26) によってなされている. 疎 行列を用いることにより，符号化の計算複雑度を $O(t n) \quad(t$ は 行列の行重み) にすることができる . また一般の線形写像では典 型集合復号や最ゆう復号が困難であるが，疎行列と確率伝搬法 (Belief-Propagation , Sum-Product アルゴリズム) ${ }^{(21),(22) を ~}$ 組み合わせることにより，復号にかかる計算複雑度を小さくす

(注45) : $\mathcal{X}$ 及び符号語のアルファベット $\{0,1\}$ が同一の有限体 (要素数 $>2$ ) に なるように拡張することは容易である

(注46) : Csiszár の論文 ${ }^{(14)}$ では, $\alpha$-復号器というものを導入していた .これは 最ゆう復号や確率分布を既知とすることを仮定しない最大エントロピー復号 (系列の 経験分布より定まるエントロピーの最大化によって再生語を求める復号法) を含む概 念である。
ることができる . 実は確率伝搬法が典型集合復号や最ゆう復号 そのものを実現しているわけではない注47)のだが, 数值実験で は情報源が定常無記憶の場合に良い復号性能か確認されている． なお，確率伝搬法は情報源が無記憶の場合でないと良い性能を 発揮でき光うにない(注48). 一方で, 疎行列による符号化と最ゆ う復号は一般の情報源に対しても良い Slepian-Wolf 符号にな ることが証明されている(36),(47)ので, 記憶のある情報源でも 良い復号法を見付けることが今後の課題であろう.最後に，有 限体上の線形写像を用いる代わりに, 実数体上の線形写像と量 子化写像を用いて Slepian-Wolf 符号を構成する試みがある ${ }^{(41)}$ ことを紹介しておく.

\section{3 ハッシュ性}

ここから, Cover と Csiszár による random binning を用い た順定理の証明を解説する . 彼らの証明では明示的には導入さ れなかったのだが, いずれの証明でもアンサンブルのハッシュ 性と呼ばれる性質が成り立つことを用いていた .

アンサンブルは, 関数族 (関数の集合) $\mathcal{A}_{n}$ と $\mathcal{A}_{n}$ 上の確率 分布 $p_{A}$ の対 $\left(\mathcal{A}_{n}, p_{A}\right)$ で与えられる. Cover の場合には $\mathcal{A}_{n}$ は $\mathcal{X}^{n}$ から $\{0,1\}^{n R_{X}}$ への関数全体, Csiszár の場合には $\mathcal{A}_{n}$ は $\{0,1\}^{n}$ から $\{0,1\}^{n R_{X}}$ への線形写像全体であり, $p_{A}$ はと もに $\mathcal{A}_{n}$ 上の一樣分布である . アンサンブルのハッシュ 性とは， 任意の $x^{n} \neq \widehat{x}^{n}$ に対して以下の不等式を満たすことである .

$$
p_{A}\left(\left\{A: A x^{n}=A \widehat{x}^{n}\right\}\right) \leqq \frac{1}{\left|\operatorname{Im} \mathcal{A}_{n}\right|}
$$

ここで, $\left|\operatorname{Im} \mathcal{A}_{n}\right|$ は関数 $A$ の值域の大きさを表す. Cover と Csiszár のアンサンブルがこの性質を持つ (注49) ことは容易に確

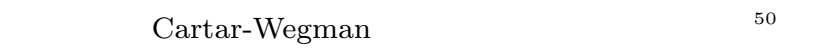
2-ユニヴァーサルハッシュ関数族と呼んで明示的に導入した ${ }^{(10)}$. これはメッセージ認証や秘密増幅などのセキュリティ分野や 計算アルゴリズムにおいて重要な概念となっている．また文 献(31) ,(39)ではこのハッシュ関数族と単一の情報源符号化問 題 (図 2) との関係か議論されている.なお, 疎行列 (LDPC 行列) のアンサンブルは (11) を満たすとは限らないので, 文 献(46) ,(47)では, 疎行列のアンサンブルを含むようにハッシュ 性の概念が拡張されている(注51).

順定理の証明には, ハッシュ性という概念から導かれる衝突 回避原理 ${ }^{(46)}$ という性質が重要である. ハッシュ関数は, 関数 の值をでたらめに決定するものであるが，条件 (11) を見ると， 衝突確率, すなわち異なる二つの系列 $x^{n}, \widehat{x}^{n}$ が同じ箱に入る 確率が, 小さくなるように設定されている .この「衝突を避け る」という性質から次の補題が証明できる.

補題 3. $\left(\mathcal{A}_{n}, p_{A}\right)$ が (11) を満たせば, 与えられた $\mathcal{X}^{n}$ の部 分集合 $\mathcal{G}_{n}$ に対して

(注47)：小さな $n$ では, 線形計画復号法を用いた最ゆう復号法 ${ }^{(33)}$ が有効である (注48) : 対応するファクターグラフが多くのループを持ってしまうため.

(注49) : 等号が成立している

(注50)：一樣分布で関数を選択することを暗に仮定する.

(注51)：この拡張は, 文献(25)，(32) か導出していた式を一般化して明示したもの である 
(a)

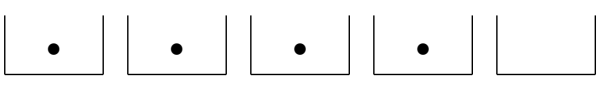

(b)

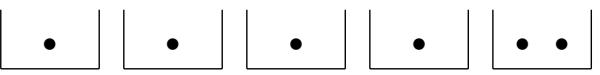

図 8 衝突回避原理 注目する $\mathcal{G}$ の要素のみを点で 表すが, 実際は $\mathcal{X}^{n}$ の要素の全てがどこかの箱 に入っている.(a) では, 点の数が箱の数より少 ないので, 異なる箱に入れることができる.(b) では, 点の数が箱の数より多いので, 衝突が避け られない .

$$
E_{A}\left[p_{X}\left(\left\{\begin{array}{c}
x^{n} \in \mathcal{G}_{n} \text { and } \\
x^{n}: \exists \widehat{x}^{n} \in \mathcal{G}_{n} \text { s.t. } \\
x^{n} \neq \widehat{x}^{n}, A x^{n}=A \widehat{x}^{n}
\end{array}\right\}\right)\right] \leqq \frac{\left|\mathcal{G}_{n}\right|}{\left|\operatorname{Im} \mathcal{A}_{n}\right|}
$$

を満たす．ここで $E_{A}$ は $p_{A}$ に関する平均を表す．

この補題より， $\mathcal{X}^{n}$ の部分集合 $\mathcal{G}_{n}$ に対して,$\frac{\left|\mathcal{G}_{n}\right|}{\left|\mathrm{m} \mathcal{A}_{n}\right|} \rightarrow 0$ と なるように $\left|\operatorname{Im} \mathcal{A}_{n}\right|$ をとれば(注52)，十分大きな $n$ と集合 $\mathcal{G}_{n} に$ 対して， $\mathcal{G}_{n}$ の要素を 1 に近い確率て違う箱に割り当てるよう な関数 $A \in \mathcal{A}_{n}$ が存在することになる (图 8).なぜなら，左 辺は失敗する確率 $\left(\mathcal{G}_{n}\right.$ の要素が同じ箱に割り当てられてしまう 確率) のランダムな $A$ の選択に関する平均を表すので, 失敗す る確率が $\frac{\left|\mathcal{G}_{n}\right|}{\left|\mathrm{m} \mathcal{A}_{n}\right|}$ 以下になる(つまり確率は 0 に収束する) よ うな $A$ が必ず存在することになる ${ }^{(\text {ì } 53)}$ からだ .これは,「衝突 を避ける」ように関数 $A$ が選択されるという性質から, 图 8(a) のような関数を自然に選択する仕組みがハッシュ性に備わって いるということにほかならない .

この補題は次のように示すことができる．

$$
\begin{aligned}
& E_{A}\left[p_{X}\left(\left\{\begin{array}{c}
x^{n} \in \mathcal{G}_{n} \text { and } \\
x^{n}: \exists \widehat{x}^{n} \in \mathcal{G}_{n} \text { s.t. } \\
x^{n} \neq \widehat{x}^{n}, A x^{n}=A \widehat{x}^{n}
\end{array}\right\}\right)\right] \\
& =\sum_{x^{n} \in \mathcal{G}_{n}} p_{X}\left(x^{n}\right) p_{A}\left(\left\{\begin{array}{c}
\exists \widehat{x}^{n} \in \mathcal{G}_{n} \text { s.t. } \\
x^{n} \neq \widehat{x}^{n}, A x^{n}=A \widehat{x}^{n}
\end{array}\right\}\right) \\
& \leqq \sum_{x^{n} \in \mathcal{G}_{n}} p_{X}\left(x^{n}\right) \sum_{\widehat{x}^{n} \in \mathcal{G}_{n} \backslash\left\{x^{n}\right\}} p_{A}\left(\left\{A: A x^{n}=A \widehat{x}^{n}\right\}\right) \\
& \leqq \frac{\left|\mathcal{G}_{n}\right|}{\left|\operatorname{Im} \mathcal{A}_{n}\right|}
\end{aligned}
$$

なお, 上記式変形で等式は足し算の順序の交換, 最初の不等式 では union bound と呼ばれる評価を, 弚の次の不等式では式 (11) を用いている.

冒頭で述べたとおり，Coverや Csiszár はハッシュ性を意識 せずに式 (11) と補題 3 を経由して順定理を証明している.式 (11) と補題 3 にハッシュ性という意味付けをしなければ彼らの

(注52) : すなわち, $\mathcal{G}_{n}$ (注目する点) の要素数はシンドローム (箱のインデック ス) の数に比べて圧倒的に小さくなる.

(注53)：ランダムに関数を構成して平均を評価することにより，平均值以下を達成 する関数の存在を保証する論法はランダム符号化論法と呼ばれ, Shannon は $\mathbf{3 . 1}$ で紹介した通信路符号化の順定理の証明においてこの論法を使った .
証明はもっと短く書けるだろう．しかしながら，ハッシュ性を経 由することにより，彼らの証明を本質から統一的に論ずること ができることと，もしも将来新たなアンサンブルが与えられた ときでも，弚のハッシュ性を確認するだけで順定理が自動的に 証明されることを強調しておきたい．

\subsection{Random Binning による順定理の証明}

ここでは, $n R_{X} \times n$ 行列のアンサンブル $\left(\mathcal{A}_{n}, p_{A}\right)$ と $n R_{Y} \times n$ 行列のアンサンブル $\left(\mathcal{B}_{n}, p_{B}\right)$ ガ共にハッシュ性を持つことを仮 定して，補題 3 を用いた順定理の証明を解説する。

$\mathcal{T}_{X Y, \varepsilon}^{n}$ を式 (10) で定義した同時典型集合とする .このとき， 復号誤り確率は次の四つの事象の確率の和で上から押えること ができる.

(i) $\left(X^{n}, Y^{n}\right) \notin \mathcal{T}_{X Y, \varepsilon}^{n}$.

(ii) $\left(X^{n}, Y^{n}\right) \in \mathcal{T}_{X Y, \varepsilon}^{n}$ であり, かつ $\widehat{x}^{n} \neq X^{n}, A \widehat{x}^{n}=$ $A X^{n}, p_{X Y}\left(X^{n}, Y^{n}\right) \leqq p_{X Y}\left(\widehat{x}^{n}, Y^{n}\right)$ を満たす $\widehat{x}^{n} \in$ $\mathcal{X}^{n}$ が存在する。

(iii) $\left(X^{n}, Y^{n}\right) \in \mathcal{T}_{X Y, \varepsilon}^{n}$ であり, かつ $\widehat{y}^{n} \neq Y^{n}, B \widehat{y}^{n}=$ $B Y^{n}, p_{X Y}\left(X^{n}, Y^{n}\right) \leqq p_{X Y}\left(X^{n}, \widehat{y}^{n}\right)$ を満たす $\widehat{y}^{n} \in$ $\mathcal{Y}^{n}$ が存在する.

(iv) $\left(X^{n}, Y^{n}\right) \in \mathcal{T}_{X Y, \varepsilon}^{n}$ であり, かつ $\widehat{x}^{n} \neq X^{n}, \widehat{y}^{n} \neq$ $Y^{n}, A \widehat{x}^{n}=A X^{n}, B \widehat{y}^{n}=B Y^{n}, p_{X Y}\left(X^{n}, Y^{n}\right) \leqq$ $p_{X Y}\left(\widehat{x}^{n}, \widehat{y}^{n}\right)$ を満たす $\left(\widehat{x}^{n}, \widehat{y}^{n}\right) \in \mathcal{X}^{n} \times \mathcal{Y}^{n}$ か存在する. ここで,(ii) 〜 (iv) は $\left(X^{n}, Y^{n}\right)$ が典型集合の要素であるの にもかかわらず最ゆう復号が失敗する事象を表している。な お，ここでは最ゆう復号を仮定したが，典型集合復号の場合 でも, 上記の条件式 (ii) 〜 (iv) に現れる不等式を兴れ光れ $\left(\widehat{x}^{n}, Y^{n}\right) \in \mathcal{T}_{X Y, \varepsilon}^{n},\left(X^{n}, \widehat{y}^{n}\right) \in \mathcal{T}_{X Y, \varepsilon}^{n},\left(\widehat{x}^{n}, \widehat{y}^{n}\right) \in \mathcal{T}_{X Y, \varepsilon}^{n}$ と 置き換えることにより同樣に証明できる .

最初に事象（ii）～(iv) の確率を評価する. 事象 (ii) の確 率を評価するために，

$$
\mathcal{G}_{n}\left(y^{n}\right) \equiv\left\{x^{n}: p_{X \mid Y}\left(x^{n} \mid y^{n}\right) \geqq 2^{-n[H(X \mid Y)+\varepsilon]}\right\}
$$

とする.(3) と同樣の導出により, $\left|\mathcal{G}_{n}\left(y^{n}\right)\right| \leqq 2^{n[H(X \mid Y)+\varepsilon]}$ で あることが分かる.一方で, $\left(X^{n}, Y^{n}\right) \in \mathcal{T}_{X Y, \varepsilon}^{n}$ であることと $\left(\widehat{x}^{n}, Y^{n}\right)$ が満たしている性質 $p_{X Y}\left(\widehat{x}^{n}, Y^{n}\right) \geqq p_{X Y}\left(X^{n}, Y^{n}\right)$ より,

$$
p_{X \mid Y}\left(\widehat{x}^{n} \mid Y^{n}\right) \geqq p_{X \mid Y}\left(X^{n} \mid Y^{n}\right) \geqq 2^{-n[H(X \mid Y)+\varepsilon]}
$$

が成立する．すなわち $\left(X^{n}, Y^{n}\right)$ と $\left(\widehat{x}^{n}, Y^{n}\right)$ は共に $\mathcal{G}_{n}\left(y^{n}\right)$ の要素である . したがって, 補題 3 の証明と同樣にして

$$
\begin{aligned}
& E_{A}\left[p_{X Y}\left(\left\{\begin{array}{c}
x^{n} \in \mathcal{G}_{n}\left(y^{n}\right) \text { and } \\
\left(x^{n}, y^{n}\right): \exists \widehat{x}^{n} \in \mathcal{G}_{n}\left(y^{n}\right) \text { s.t. } \\
x^{n} \neq \widehat{x}^{n}, A x^{n}=A \widehat{x}^{n}
\end{array}\right\}\right)\right] \\
& \leqq \sum_{y^{n} \in \mathcal{Y}^{n}} \frac{p_{Y}\left(y^{n}\right)\left|\mathcal{G}_{n}\left(y^{n}\right)\right|}{\left|\operatorname{Im} \mathcal{A}_{n}\right|} \\
& \leqq 2^{-n\left[R_{X}-H(X \mid Y)-\varepsilon\right]}
\end{aligned}
$$


が示される．ここで，最後の不等式では $\left|\mathcal{G}_{n}\left(y^{n}\right)\right|$ の評価と $\left|\operatorname{Im} \mathcal{A}_{n}\right|=2^{n R_{X}}$ であることを用いた . 事象 (iii) の確率につ いても

$$
\mathcal{G}_{n}\left(x^{n}\right) \equiv\left\{y^{n}: p_{Y \mid X}\left(y^{n} \mid x^{n}\right) \geqq 2^{-n[H(Y \mid X)+\varepsilon]}\right\}
$$

を考えれば，同樣にして

$$
\begin{aligned}
& E_{B}\left[p_{X Y}\left(\left\{\left(x^{n}, y^{n}\right): \begin{array}{l}
y^{n} \in \mathcal{G}_{n}\left(x^{n}\right) \text { and } \\
\widehat{y}^{n} \in \mathcal{G}_{n}\left(x^{n}\right) \text { s.t. } \\
y^{n} \neq \widehat{y}^{n}, B y^{n}=B \widehat{y}^{n}
\end{array}\right\}\right)\right] \\
& \leqq 2^{-n\left[R_{Y}-H(Y \mid X)-\varepsilon\right]}
\end{aligned}
$$

を得る.事象 (iv) の確率についても集合

$$
\mathcal{G}_{n} \equiv\left\{\left(x^{n}, y^{n}\right): p_{X Y}\left(x^{n}, y^{n}\right) \geqq 2^{-n[H(X, Y)+\varepsilon]}\right\}
$$

を考えれば，同樣にして

$$
\begin{aligned}
& E_{A B}\left[p_{X Y}\left[\left\{\begin{array}{c}
\left(x^{n}, y^{n}\right) \in \mathcal{G}_{n} \text { and } \\
\exists\left(\widehat{x}^{n}, \widehat{y}^{n}\right) \in \mathcal{G}_{n} \text { s.t. } \\
x^{n} \neq \widehat{x}^{n}, A x^{n}=A \widehat{x}^{n} \\
y^{n} \neq \widehat{y}^{n}, B x^{n}=B \widehat{x}^{n}
\end{array}\right\}\right)\right] \\
& \leqq 2^{-n\left[R_{X}+R_{Y}-H(X, Y)-\varepsilon\right]}
\end{aligned}
$$

を得る．以上のことから，ランダム符号化論法により，任意の $n$ である関数 $A, B$ が存在して, 復号誤り確率が

$$
\begin{aligned}
& \operatorname{Prob}\left(\left(X^{n}, Y^{n}\right) \notin \mathcal{T}_{X Y, \varepsilon}^{n}\right)+2^{-n\left[R_{X}-H(X \mid Y)-\varepsilon\right]} \\
& \quad+2^{-n\left[R_{Y}-H(Y \mid X)-\varepsilon\right]}+2^{-n\left[R_{X}+R_{Y}-H(X, Y)-\varepsilon\right]}
\end{aligned}
$$

以下になっている.ここで, 補題 1 と同樣に $n \rightarrow \infty$ とともに $\operatorname{Prob}\left(\left(X^{n}, Y^{n}\right) \in \mathcal{T}_{X Y, \varepsilon}^{n}\right) \rightarrow 1$ となるので, 初項の事象 (i) の 確率は 0 に収束する.一方で, 条件 $(4) \sim(6)$ を満たしてい れば適切な $\varepsilon>0$ をとることにより第 $2 \sim 4$ 項が 0 に収束する ことが分かる. 以上より, 条件 $(4) \sim(6)$ を満たすレート対 $\left(R_{X}, R_{Y}\right)$ を持ち, 復号誤り確率が 0 に収束する符号 (関数 $A$, $B$ の列) の存在が証明された .

\subsection{Wyner の証明と Csiszár の証明についての 補足}

Wyner は差分 $Z^{n} \equiv Y^{n}-X^{n}$ のシンドローム $A Z^{n}$ が $Y^{n}$ のシンドローム $A Y^{n}$ と $X^{n}$ 符号語となるシンドローム $A X^{n}$ から得られることを利用して, $(H(X \mid Y), H(Y))$ 付近のレート を達成する符号を構成した . Wyner はコセット符号を用いたの で, $A X^{n} \neq 0^{n R_{X}}$ の場合にも復号誤り確率が 0 になることは 自明ではないと思うのであるが, $A X^{n} \neq 0^{n R_{X}}$ の場合にも復 号誤り確率が 0 に収束するということを証明抜きで主張してい る.恐らくWyner はこの主張を示すために, 通信路の対称性 より全てのコセット符号が同じ誤り確率を持つこと注54) を用い

(注54)：この事実は文献(4)で示されている.

\section{たと思われる．}

一方で Csiszár の証明を一つの情報源という特殊な場合（図 2) に適用することにより，任意の情報源 $Z^{n}$ のシンドローム $A Z^{n}$ から $Z^{n}$ が 0 に近い復号誤り確率で復号できるような行 列 $A$ の存在を示すことができる(注55). 光して $Z^{n} \equiv Y^{n}-X^{n}$ と置くことによりWyner の主張を得る . なお, Csiszár の証明 では通信路の概念は登場しない. 実は補題 2 も Csiszár の方針 で証明することができるが, Elias ${ }^{(2)}$ の証明にはこのことが明示 的に現れていない .

\section{Slepian-Wolf 符号から通信路符号人}

前章の最後で説明したように, Csiszár ${ }^{(14)}$ によって, Wyner ${ }^{(7)}$ によるパリティ検査行列の方法と random binning の方法が結 び付いた .ここで, Csiszár の証明は Wyner の証明とは異な り，一般の (非対称な) 相関を有する情報源に対して成立する ことを強調しておきたい .この事実は, 通信路の対称性を仮定 して証明されていたパリティ検査行列による通信路符号 (図 5 ) の存在定理 (補題 2) を, 対称性を仮定せずに証明できる可能性 を示唆している . この章では Slepian-Wolf の定理から少し脱線 して, 対称性を仮定しない一般の通信路に対する符号を，パリ ティ検査行列による Slepian-Wolf 符号 (図 6 の補助情報を伴 う情報源符号) から構成してみたい .

パリティ検査行列による Slepian-Wolf 符号から通信路符号 を構成する方法は典型集合を用いる方法 ${ }^{(36)}$ と二つのパリティ検 査行列を用いる方法 ${ }^{(44),(46),(53)}$ があるが，ここでは，直観的 な証明が容易な典型集合を用いた方法を紹介する．

$X^{n}, Y^{n}$ を光れ光れ対称性を仮定しない一般の定常無記憶 通信路(注56) の入力, 出力とする. 光して以下では $\left(X^{n}, Y^{n}\right)$ を相関のある情報源とみなす，循環論法を避けるために，八 ッシュ性を持つアンサンブル $\left(\mathcal{A}_{n}, p_{A}\right)$ の存在だけを仮定す

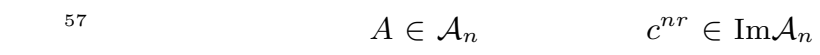
$(r$ は後で定める) を符号器と復号器で共有しておく.メッ セージの集合を $\{0,1\}^{n R} \quad(R$ は後で決まる $)$ として, 全単 射 $f_{A}\left(\cdot \mid c^{n r}\right):\{0,1\}^{n R} \rightarrow \mathcal{T}_{X, \varepsilon}^{n} \cap \mathcal{C}_{A}\left(c^{n r}\right)$ を用意し，これ も符号器と復号器で共有しておく.ここで, $\mathcal{T}_{X, \varepsilon}^{n}$ は式 (2) で定義した典型集合, $\mathcal{C}_{A}\left(c^{n r}\right)$ は $c^{n r}$ より定まるコセット $\mathcal{C}_{A}\left(c^{n r}\right) \equiv\left\{x^{n}: A x^{n}=c^{n r}\right\}$ である.

通信路符号は以下のような構成になる (図 9).ここで, $g_{A}$ は シンドローム $c^{n r}$ と補助情報 $Y^{n}$ から $X^{n}$ を再生する SlepianWolf 復号器 (最ゆう復号器) である.すなわち, $g_{A}$ は以下で 定義される.

$$
g_{A}\left(c^{n r} \mid y^{n}\right) \equiv \arg \max _{\widehat{x}^{n}: A \widehat{x}^{n}=c^{n r}} p_{X Y}\left(\widehat{x}^{n}, y^{n}\right)
$$

- 符号器はメッセージ $M^{n R} \in\{0,1\}^{n R}$ に対して, 全単射 $f_{A}\left(\cdot \mid c^{n r}\right)$ を用いて符号語 $X^{n}$ を求める. 符号器は以下のよう

(注55) : これは定理 1 の符号が線形写像の符号器と最ゆう復号器で構成できること を意味する。

(注56)：定常無記憶性を仮定しない一般の通信路の場合は文献(53) で扱われている (注 57) : 関数の線形性を仮定する必要はないが, 以後, シンドロームやコセットな ど，線形符号の用語を用いて説明する． 
になる .

$$
\phi_{n}\left(m^{n R}\right) \equiv f_{A}\left(m^{n R} \mid c^{n r}\right)
$$

- 復号器は $g_{A}$ を用いて $\widehat{X}^{n}$ を再生し(注58),$f_{A}\left(\cdot \mid c^{n r}\right)$ の 逆写像 $f_{A}^{-1}\left(\cdot \mid c^{n r}\right)$ を用いてメッセージ $\widehat{M}^{n R} \equiv f_{A}^{-1}\left(\widehat{X}^{n} \mid c^{n r}\right)$ を再生する . 復号器は以下のようになる .

$$
\psi_{n}\left(y^{n}\right) \equiv f_{A}^{-1}\left(\arg \max _{\widehat{x}^{n}: A \widehat{x}^{n}=c^{n r}} p_{X Y}\left(\widehat{x}^{n}, y^{n}\right) \mid c^{n r}\right)
$$

4.4 にある証明から , $\left(X^{n}, Y^{n}\right) \in \mathcal{T}_{X Y, \varepsilon}^{n}$ であり, かつ $r=H(X \mid Y)+\varepsilon$ を満たしていれば, $\widehat{X}^{n} \neq X^{n}$ となる確率が 0 に収束するような関数 $A$ の存在を示すことができる(注59).$し$ たがって,$f_{A}\left(\cdot \mid c^{n r}\right)$ が全単射であることから,$M^{n R} \neq \widehat{M}^{n R}$ となる復号誤り確率は 0 に近いはずである . 以上の議論は $c^{n r}$ がどんな值であっても成立することを注意しておく

さて，このように構成した符号でメッセージ集合 $\{0,1\}^{n R}$ の 要素数をどのくらいまで大きくできるであろうか? $f_{A}\left(\cdot \mid c^{n r}\right)$ が 全単射であることから，|\{0,1 $\}^{n R}|=| \mathcal{T}_{X, \varepsilon}^{n} \cap \mathcal{C}_{A}\left(c^{n r}\right) \mid$ を満た している.一方で，

$$
\begin{aligned}
\max _{c^{n r} \in \operatorname{Im} \mathcal{A}_{n}}\left|\mathcal{T}_{X, \varepsilon}^{n} \cap \mathcal{C}_{A}\left(c^{n r}\right)\right| & \geqq \sum_{c^{n r} \in \operatorname{Im} \mathcal{A}_{n}} \frac{\left|\mathcal{T}_{X, \varepsilon}^{n} \cap \mathcal{C}_{A}\left(c^{n r}\right)\right|}{\left|\operatorname{Im} \mathcal{A}_{n}\right|} \\
& =\frac{\left|\mathcal{T}_{X, \varepsilon}^{n}\right|}{\left|\operatorname{Im} \mathcal{A}_{n}\right|} \\
& \geqq \frac{2^{n[H(X)-\varepsilon]}}{2^{n[H(X \mid Y)+\varepsilon]}} \\
& =2^{n[H(X)-H(X \mid Y)-2 \varepsilon]}
\end{aligned}
$$

が成り立つ.ここで, 最初の等式ではコセットが $\mathcal{X}^{n}$ を互いに素 な集合に分割していることを，二番目の不等式では典型集合の大 きさの評価式 $\left|\mathcal{T}_{X, \varepsilon}^{n}\right| \geqq 2^{n[H(X)-\varepsilon]}$ と関係式 $r=H(X \mid Y)+\varepsilon$ を用いた・したがって，

$$
\left|\{0,1\}^{n R}\right|=\left|\mathcal{T}_{X, \varepsilon}^{n} \cap \mathcal{C}_{A}\left(c^{n r}\right)\right| \geqq 2^{n[H(X)-H(X \mid Y)-2 \varepsilon]}
$$

を満たす $c^{n r} \in \operatorname{Im} \mathcal{A}_{n}$ を選ぶことにより符号化レートを $[H(X)-H(X \mid Y)-2 \varepsilon]$ 以上にできることが分かった . 通信路 容量 $\max _{X}[H(X)-H(X \mid Y)]$ を達成する $X$ をとり, $n \rightarrow \infty$, $\varepsilon \rightarrow 0$ とすることにより, Slepian-Wolf 復号器を用いて構成し た通信路符号で通信路容量を達成できることが分かる．

ここで, 提案した通信路符号と通常の線形符号の違いを補足 しておく . 通常の線形符号 (コセット符号) では $\mathcal{C}_{A}\left(c^{n r}\right)$ を符 号語集合としていた . $X$ が等確率分布を持てば, $\mathcal{C}_{A}\left(c^{n r}\right)$ の全 てが典型系列 $\left(\mathcal{T}_{X, \varepsilon}^{n}\right.$ の要素) となり, 復号誤り確率は 0 に収束 する. 光して二元対称通信路では $X$ が等確率分布を持つときに 通信路容量を達成するので, 通常の線形符号により通信路容量 $[1-H(X \mid Y)]$ を達成できた .このように線形符号は $X$ が等 確率分布を持つように設計されているはずなので, 通信路容量 $\max _{X}[H(X)-H(X \mid Y)]$ を達成する $X$ が等確率分布を持た ないときは最適であるとは限らない，一方で，提案した通信路 符号では符号語集合を $\mathcal{T}_{X, \varepsilon}^{n} \cap \mathcal{C}_{A}\left(c^{n r}\right)$ に制限することにより，

(注58) : $A X^{n}=c^{n r}$ を満たしていることに注意

(注59) : 図 6 の設定を考えながら 4.4 にある事象 (ii) の評価を確認してほしい .
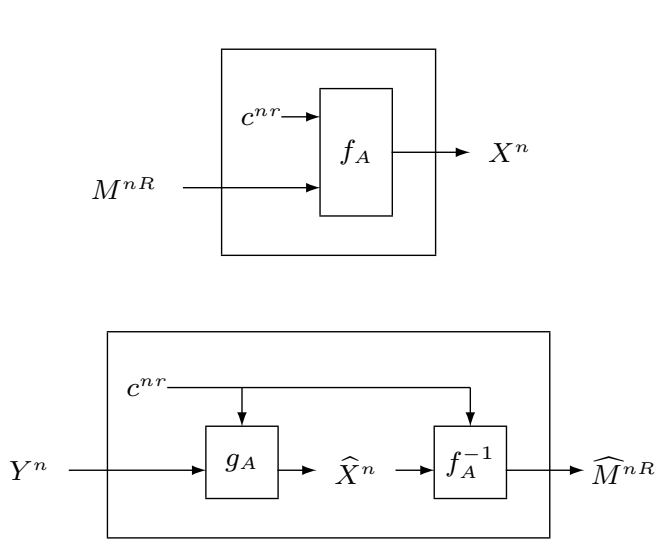

図 9 通信路符号の構成

入力系列が全て典型系列になるように工夫されている .これに よって，X が等確率分布を持たないときに通信路容量を達成す る場合でも，符号化レートが通信路容量を達成しながら，同時 に復号誤り確率が 0 に収束することを保証することができた．

なお，提案した方法は通常の線形符号と異なり，符号器はも はや線形写像にはならない可能性がある．したがって，提案方 法では全単射 $f_{A}\left(\cdot \mid c^{n r}\right)$ を用意するのが困難かも知れない．こ の欠点を補うために，疎行列と確率伝搬法を利用した実装方法 が文献(53) で提案されている．また，提案方法にある最ゆう復 号も計算が困難であるが, これも疎行列と確率伝搬法を用いた 復号と置き換えて実装すれば実行可能となり，弚れでも良い性 能が得られることが期待される．確率伝搬法を用いた構成の理 論解析については今後の課題である .

このように，Slepian-Wolf 符号と通信路符号には双対

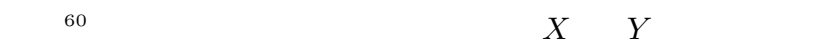
路の入出力となっているような相関を有する場合において， Slepian-Wolf 符号と通信路符号の双対性が文献(38),(45)で考 察されていることを紹介しておく．

\section{6. 明示的な符号の構成}

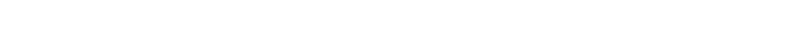
中に良い符号の存在を示すというランダム符号化論法を用いてい た .一方で, 決定的に構成された Slepian-Wolf 符号を与えてい るものとして文献(24)，(34)，(35)がある．これらの論文では， 長さ $N$ のブロックを複数の小さなサブブロックに分割して关れ 光れを異なる符号を用いて符号化することにより，全体のブロッ クの復号シンボル誤り率(注61)が 0 に近い符号を構成している. 文献 (24) は代数的符号のクラスを用いており, 文献(34),(35)

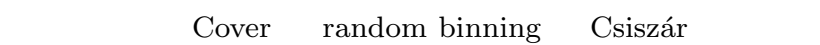
像による random binning を用いている(注62) . サブブロックの 大きさを $n \equiv O(\log N)$ とすることにより，光れぞれのサブブ ロックの復号時間を $O(N)$ にできる . トータルの復号時間は

(注60)：一方の符号があれば他方の符号が構成できることを指す

(注61) $: x^{N}$ の中で復号誤りとなったシンボルの個数を $N$ で割った值

(注62) : 文献(24) ではサブブロックの符号の更新順序は固定されているが，文 献(34)，(35) では情報源出力のランダムネスを利用して符号の更新を行っている. 
$O\left(N^{2} / \log N\right)$ になる .ここで，

[シンボル誤り率 $] \leqq \frac{1}{N} \cdot[$ サブブロックの個数 $]$

$$
\begin{aligned}
& \text { ·[復号に失敗するサブブロックの割合 }] \\
& \cdot[\text { サブブロックの長さ }] \\
= & {[\text { 復号に失敗するサブブロックの割合 }] }
\end{aligned}
$$

から , シンボル誤り率はサブブロックの復号に失敗する割合以 下になる . サブブロックの復号に失敗する割合とは , 長さ $n$ の ブロックの復号誤り確率にほかならない，光して，ランダム符 号化論法と同じ評価により, ブロック長 $n$ の符号の選択に関す る平均復号誤り確率は $n \rightarrow \infty$ とともに 0 に収束することが分 かる.これより，シンボル誤り率も 0 に収束する.

文献(24),(34)では更に , シンボル誤りを訂正するための冗 長な情報をほんの少し付加する (冗長部分の符号化レートは 0 ) ことにより，長さ $N$ のブロックの誤り率を 0 に近づける符号を 構成している.なお，この補正のために必要な復号計算複杂倠度 は $N$ の多項式オーダーである.最後に, 復号シンボル誤り率が 0 に近い符号を構成したものとして文献 $(29)$ を紹介しておく.

\section{7. おわりに}

くしくも Slepian-Wolf の定理の発表からちょうど 40 年 ${ }^{\text {(注63) }}$ で ある. 実装不可能と思われていたのか, 光れともニーズがないと みなされていたのか, 実装に関する研究の多くは今世紀に入って からであつた . これには 1990 年代のターボ符号の発明や LDPC 符号の再発見など, 通信路容量を達成する符号の開発が進んだ ことが影響したのは間違いないだろう．また, 動画像やセンサ ネットワークなど, Slepian-Wolf 符号が適用でき㶢うな情報源 が身近になったことも実装研究が進んだ理由の一つだろう.

一方で, Slepian-Wolf の定理は理論面において樣々なバリ エーションを生んだ. Slepian-Wolf の定理から発展した(復号 時に生じるひずみを許す符号化を含む）多端子情報源符号化の バリエーションについては文献(11)，(13)，(40)か詳しい .

Slepian と Wolf による最初の発想は Shannon の二つの符号 化定理 ${ }^{(1)}$ を応用した大変素朴なものであった . 今では Cover に よる単純明解な証明があるので, 彼らの証明が取り上げられる ことは滅多にないかもしれない，しかしながら, 素朴なアイデ アから出た結論は当時の研究者たちを驚かせたに違いなく(注64), その驚きを少しでも感じとって頂ければ本望である. Shannon の最初の論文が光うであったように，素朴なアイデアから意外 な結論を導くというのか情報理論の面白さの一つかなと小生は 考えている.例えば 5. て紹介した考え方を応用すれば，情報理 論のあらゆる順定理が証明でき乥うである ${ }^{(46) \sim(48),(52),(53) 。 ~}$ これが真実なら Slepian-Wolf の定理は情報理論の基本原理で あるといえるのではないだろうか . また何かの折に , このこと についてお話しする機会があればと申し上げて，本稿のおわり とさせて頂きたい .

\section{(注63) : 本稿の執筆時}

(注64) : 文献(12)でも言及されているが, Shannon の最初の論文 ${ }^{(1)}$ から SlepianWolf の論文 ${ }^{(5)}$ の間に 25 年もたっていることか驚きである.
謝辞 本稿は, 2013 年 3 月に岐阜大学で行われた電子情報通 信学会総合大会において, 故 J. K. Wolf 先生を追悼するチュー トリアル講演でお話した内容を基にしました . チュートリアル 講演でお世話になった㞳阜大学の鎌部浩先生, 本誌編集委員と してお世話になった電気通信大学の八木秀樹先生, 東京大学の 國廣昇先生に感謝申し上げます．また，執筆にあたり情報を頂 いた, 電気通信大学の森田啓義先生, 東京工業大学の植松友彦 先生, Princeton 大学の S. Verdú 先生, NTT 未来ねつと研究 所の仲地孝之主任研究員に感謝申し上げます.最後に, 本稿の 原稿を丁寧に読んで頂き, 樣々な助言をして頂いた閲読者お二 人の先生方, 福井大学の岩田賢一先生, NTT 未来ねつと研究所 の三宅茂樹主任研究員, NTT コミュニケーション科学基礎研究 所の新井賢一主任研究員に感謝申し上げます．

\section{文献}

(1) C. E. Shannon, "A mathematical theory of communication," Bell Syst. Tech. J., vol. 27, pp. 379-423, 623-656, 1948.

(2) P. Elias, "Coding for noisy channels," IRE Convention Record, Part 4, pp. 37-46, 1955.

(3) R. G. Gallager, "Low density parity check codes," IRE Trans. Inform. Theory, vol. IT-8, pp. 21-28, Jan. 1962.

(4) R. G. Gallager, Information Theory and Reliable Communication, John Wiley \& Sons, Inc., 1968.

(5) D. Slepian and J. K. Wolf, "Noiseless coding of correlated information sources," IEEE Trans. Inf. Theory, vol. IT-19, no. 4, pp. 471-480, July 1973.

(6) D. Slepian and J. K. Wolf, "A coding theorem for multiple access channels with correlated sources," Bell Syst. Tech. J., vol. 52, no. 7, pp. 1037-1076, Sept. 1973.

(7) A. D. Wyner, "Recent results in the Shannon theory," IEEE Trans. Inf. Theory, vol. IT-20, no. 1, pp. 2-10, Jan. 1974.

(8) T. M. Cover, "A proof of the data compression theorem of Slepian and Wolf for ergodic sources," IEEE Trans. Inf. Theory, vol. IT-21, no. 2, pp. 226-228, March 1975.

(9) H. S. Witsenhausen, "The zero-error side information problem and chromatic numbers," IEEE Trans. Inf. Theory, vol. IT-22, pp. 592-593, Sept. 1976.

(10) J. L. Carter and M. N. Wegman, "Universal classes of hash functions," J. Comput. Syst. Sci., vol. 18, pp. 143154, 1979.

（11）韓 太舜, “多元情報源に対する符号化定理,”数理科学, no. 202, pp. 34-41, April 1980.

（12）有本 卓, 確率・情報・エントロピー, 森北出版, 東京, 1980 .

(13) I. Csiszár and J. Körner, Information Theory: Coding Theorems for Discrete Memoryless Systems, Academic Press, 1981. (2nd Ed.: Cambridge University Press, 2011.)

(14) I. Csiszár, "Linear codes for sources and source networks: Error exponents, universal coding," IEEE Trans. Inf. Theory, vol. IT-28, no. 4, pp. 585-592, July 1982.

(15) Y. Oohama and T. S. Han, "Universal coding for Slepian-Wolf data compression system and the strong converse theorem," IEEE Trans. Inf. Theory, vol. 40, no. 6, pp. 1908-1919, Nov. 1994.

(16) S. Miyake and F. Kanaya, "Coding theorems on correlated general sources," IEICE Trans. Fundamentals, vol. E78-A, no. 9, pp. 1063-1070, Sept. 1995.

(17) C. Berrou and A. Glavieux, "Near optimum errorcorrecting coding and decoding: Turbo codes," IEEE Trans. Commun., vol. 44, no. 10, pp. 1261-1271, 1996.

（18）韓 太舜, 情報理論における情報スペクトル的方法, 培風館, 
1998. (英語版：T. S. Han, Information-Spectrum Methods in Information Theory, Springer, 2003.)

（19）情報源符号化一無歪みデータ圧縮, 情報理論と光の応用学会 (編)，培風館, 1998 .

(20) D. J. C. MacKay, "Good error-correcting codes based on very sparse matrices," IEEE Trans. Inf. Theory, vol. IT-45, no. 2, pp. 399-431, March 1999.

(21) S. M. Aji and R. J. McEliece, "The generalized distributive law," IEEE Trans. Inf. Theory, vol. 46, no. 2, pp. 325-343, March 2000.

(22) F. R. Kschischang, B. J. Frey, and H. A. Loeliger, "Factor graphs and the sum-product algorithm," IEEE Trans. Inf. Theory, vol. 47 , no. 2, pp. 498-519, Feb. 2001.

(23) J. Garcia-Frias and Y. Zhao, "Compression of correlated binary memoryless sources using turbo codes," IEEE Commun. Lett., vol. 5, no. 10, pp. 417-419, Oct. 2001.

(24) T. Uyematsu, "An algebraic construction of codes for Slepian-Wolf source networks," IEEE Trans. Inf. Theory, vol. IT-47, no. 7, pp. 3082-3088, Nov. 2001.

(25) G. Miller and D. Burshtein, "Bounds on the maximumlikelihood decoding error probability of low-density parity-check codes," IEEE Trans. Inf. Theory, vol. IT47, no. 7, pp. 2696-2710, Nov. 2001.

(26) T. Murayama, "Statistical mechanics of data compression theorem," J. Phys. A, Math. Gen., vol. 35, L95L100, March 2002.

(27) A. D. Liveris, Z. Xiong, and C. N. Georghiades, "Compression of binary sources with side information at the decoder using LDPC codes," IEEE Commun. Lett., vol. 6 , no. 10 , pp. $440-442$, Oct. 2002.

(28) D. Schonberg, S. S. Pradhan, and K. Ramchandran, "LDPC codes can approach the Slepian Wolf bound for general binary sources," 40th Annual Allerton Conference on Communication, Control, and Computing, Allerton House, Monticello, Illinois, Oct. 2002.

(29) Q. Zhao and M. Effros, "Lossless and near-lossless source coding for multiple access networks," IEEE Trans. Inf. Theory, vol. IT-49, no. 1, pp. 112-128, Jan. 2003.

（30）村松 純，“相関のある情報源の符号化と光の応用，”信学技報， IT2003-53, pp. 25-30, Dec. 2003.

(31) D. J. C. MacKay, Information Theory, Inference, and Learning Algorithms, Cambridge University Press, 2003.

(32) A. Bennatan and D. Burshtein, "On the application of LDPC codes to arbitrary discrete-memoryless channels," IEEE Trans. Inf. Theory, vol. IT-50, no. 3, pp. 417-438, March 2004.

(33) J. Feldman, M. J. Wainwright, and D. R. Karger, "Using linear programming to decode binary linear codes," IEEE Trans. Inf. Theory, vol. IT-51, no. 3, pp. 954-972, March 2005.

(34) J. Muramatsu, "Source coding algorithms using the randomness of a past sequence," IEICE Trans. Fundamentals, vol. E88-A, no. 4, pp. 1063-1083, April 2005.

(35) J. Muramatsu and T. Mukouchi, "Simulated random coding algorithm for Correlated Sources with Ensemble of Linear Matrices," IEICE Trans. Fundamentals, vol. E88-A, no. 9, pp. 2475-2480, Sept. 2005.

(36) J. Muramatsu, T. Uyematsu, and T. Wadayama, "Low density parity check matrices for coding of correlated sources," IEEE Trans. Inf. Theory, vol. IT-51, no. 10, pp. 3645-3653, Oct. 2005.

(37) J. Muramatsu, "Secret key agreement from correlated source outputs using low density parity check matrices," IEICE Trans. Fundamentals, vol. E89-A, no. 7, pp. 2036-2046, July 2006.

(38) D.-k. He and E.-h. Yang, "On the duality between Slepian-Wolf coding and channel coding," Proc. 2006 IEEE Int. Symp. Inf. Theory, Seattle, pp.2546-2550,
USA, July 2006.

(39) H. Koga, "Source coding using families of universal hash functions," IEEE Trans. Inf. Theory, vol. 53, no. 9, pp. 3226-3233, Sept. 2007.

（40）大濱靖匡，“多端子情報源符号化の研究と未解決問題,” IEICE Fundamentals Review, vol. 2, no. 2, pp. 40-52, Oct. 2008.

(41) S. Shenvi, B. K. Dey, S. Jaggi, and M. Langberg, " Real' Slepian-Wolf codes," Proc. IEEE Int. Symp. Inf. Theory, pp. 1423-1427, Seoul, Korea, June-July 2009.

(42) N. Hussami, S. B. Korada, and R. Urbanke, "Performance of polar codes for channel and source coding," Proc. 2009 IEEE Int. Symp. Inf. Theory, pp. 1488-1492, Seoul, Korea, June-July 2009.

(43) E. Arıkan, "Channel polarization: A method for constructing capacity-achieving codes for symmetric binary-input memoryless channels," IEEE Trans. Inf. Thoery, vol. 55, no. 7, pp. 3051-3073, July 2009.

(44) S. Miyake and J. Muramatsu, "A construction of channel code, JSCC and universal code for Arbitrary Stationary memoryless channels using sparse matrices," IEICE Trans. Fundamentals, vol. E92-A, no. 9, pp. 2333-2344, Sept. 2009.

(45) J. Chen, D.-k. He, A. Jagmohan, L. A. LastrasMontaño, and E.-h. Yang, "On the linear codebooklevel duality between Slepian-Wolf coding and channel coding," IEEE Trans. Inf. Theory, vol. IT-55, no. 12, pp. 5575-5590, Dec. 2009.

(46) J. Muramatsu and S. Miyake, "Hash property and coding theorems for sparse matrices and maximallikelihood coding," IEEE Trans. Inf. Theory, vol. IT-56, no. 5, pp. 2143-2167, May 2010. (Corrections: vol.IT56 , no.9, p. 4762, Sept. 2010, vol. IT-59, no. 10, pp. 6952-6953, Oct. 2013.)

(47) J. Muramatsu and S. Miyake, "Construction of SlepianWolf source code and broadcast channel code based on hash property," available at arXiv:1006.5271[cs.IT], 2010 .

(48) J. Muramatsu and S. Miyake, "Construction of multiple access channel codes based on hash property," available at arXiv:1006.6719[cs.IT], 2010.

(49) R. Nomura and T. Matsushima, "An analysis of Slepian-Wolf coding problem based on the asymptotic normality," IEICE Trans. Fundamentals, vol. E94-A, no. 11, pp. 2220-2225, Nov. 2011.

(50) V. Y.F. Tan and O. Kosut, "The dispersion of SlepianWolf coding," Proc. 2012 IEEE Int. Symp. Inform. Theory, pp.920-924, Boston, USA, July 2012.

(51) T. M. Cover, J. A. Thomas, 情報理論一基礎と広がり, 共 立出版，2012. (原著: T. M. Cover and J. A. Thomas, Elements of Information Theory 2nd. Ed., John Wiley \& Sons, Inc., 2006.)

(52) J. Muramatsu and S. Miyake, "Construction of codes for wiretap channel and secret key agreement from correlated source outputs based on hash property," IEEE Trans. Inf. Theory, vol. IT-58, no. 2, pp. 671-692, Feb. 2012.

(53) J. Muramatsu, "Constructions of codes for general channel and lossy code for general source," Proc. Symp. Inform. Theory and its Applicat., pp. 184-189, Beppu, Oita, Japan, Dec. 2012.

(54) R. Nomura and T. S. Han, "Second-order Slepian-Wolf source coding theorems," Proc. Symp. Inform. Theory and its Applicat., pp. 356-361, Beppu, Oita, Japan, Dec. 2012.

（55）仲地孝之, “分散情報源定理とメディア処理への応用,” 信学技報, vol. IT2012-100, pp. 241-246, March 2013.

（56）渡辺 峻, “情報理論的に安全な秘密鍵共有と周辺話題一データ 圧縮と乱数生成のコラボレーション," IEICE Fundamentals Review, vol. 7, no. 1, pp. 38-50, July 2013.

（57）村松 純, “Slepian-Wolf の定理,” 2013 信学総大, no. AT3-2, March 2013 
(IT 研究会提案, 平成 25 年 9 月 24 日受付

10 月 29 日最終受付)

村松 純 (正員)

1990 名大 $\cdot$ 理. 数学卒. 1992 名大大学院理学研 究科数学専攻博士前期課程了. 1992 日本電信電話株 式会社入社. 1998 名大大学院人間情報学研究科論文 博士 (学術). 情報理論の研究に従事. 平 19 第 63 回本会論文賞受賞 . 